\title{
LAS METAMORFOSIS DEL TRABAJO: DEL TRABAJO AL EMPLEO (NOTAS DE LECTURA PARA UNA RECONSTRUCCIÓN HISTÓRICA-CONCEPTUAL DEL TRABAJO)
}

\author{
Marcos López Oneto* \\ Universidad Andres Bello
}

"El trabajo, más que la risa, sin duda, es lo propio del hombre".

\begin{abstract}
"Aquellos hombres que difieren tanto de los demás como el cuerpo del alma o la bestia del hombre (y según este modo están dispuestos aquellos cuyo función es el uso del cuerpo, y esto es lo mejor que de ellos cabe esperar) son por naturaleza esclavos, y para ellos es mejor ser mandados con este género de mando (...) Es pues esclavo por naturaleza el que puede pertenecer a otro (y por esto es de otro) y que participa de la razón en cuanto puede percibirla, pero sin tenerla en propiedad".

"Por proletarios se comprende la clase de los trabajadores asalariados modernos, que, privados de medios de producción propios, se ven obligados a vender su fuerza de trabajo"s.
\end{abstract}

"Nos enfrentamos con la perspectiva de una sociedad de trabajadores sin trabajo, es decir, sin la única actividad que les queda. Está claro que nada podría ser peor"4

RESUMEN: A lo largo de la historia de la humanidad, el trabajo ha reconocido diversas formas y estructuras jurídicas, antropológicas y sociológicas. En este íter de cambios morfológicos, la realidad socio-jurídica que distinguimos contemporáneamente con el término empleo, es el estadio actual predominante de desarrollo del trabajo. Vale decir, el empleo es una especie de la categoria genérica trabajo. En esta investigación, esencialmente, revisamos la evolución del trabajo hacia el empleo. Ese es nuestro norte. Histórica y dialécticamente, la relación jurídica y social que referimos con el palabra empleo, puede ser comprendida como una especie de trabajo superadora de la esclavitud, la servidumbre y otras subespecies de vasallaje; del trabajo corporativo y de cualquier otra forma de trabajo que no pueda desarrollarse con plena libertad e igualdad jurídicas. Siendo la forma normativa jurídica típica del trabajo dependiente de la época fordista del capitalismo, el empleo ha evolucionado y sigue evolucionando lo mismo que el sistema capitalista de producción.

Palabras claves: trabajo, empleo, esclavitud, protestantismo, capitalismo, derecho del trabajo

ABSTRACT: Throughout the history of mankind, work has recognized various legal, anthropological and sociological forms and structures. In this iteration of morphological changes, the socio-legal reality that

\footnotetext{
Abogado. Director del Departamento de Derecho del Trabajo y de la Seguridad Social de la Universidad Andrés Bello. Licenciado en Ciencias Jurídicas y Sociales, Magíster en Derecho con mención en Derecho Privado y Doctor en Derecho, por la Universidad de Chile.

1 Nougier, Louis-René. "La prehistoria", en: Parias, Louis-Henri. Historia General del Trabajo. Tomo I, traducción Joaquín Romero Maura. México: Ediciones Grijalbo, 1965, p. 15.

2 Aristóteles. Ética Nicomaquea. Política. México: Harla, 1990, pp. 194-195.

3 Nota de Federico Engels a la edición inglesa de 1888 del "Manifiesto del Partido Comunista". Marx, Carlos; EngELs, Federico. Obras Escogidas. Tomo I. Moscú, Rusia: Editorial Progreso, 1976, p. 111.

4 Arendt, Hannah. La condición humana. Traducción Ramón Gil Novales. Buenos Aires, Argentina: Ediciones Paidós, 2009, p. 17.
} 
Marcos López Oneto / Las metamorfosis del trabajo: del trabajo al empleo

we distinguish contemporaneously with the word employment is the actual predominant stage of development of work. That is to say, that employment is a kind of generic category of work. In this investigation, we essentially review the evolution of work toward employment. That is our north. Historically and dialectically, the legal and social relationship to which we refer with the word employment perhaps is to be understood as a kind of work that overcomes slavery, servitude and other subspecies of vassalage; corporate work and any other form of work that cannot be developed in full freedom and legal equality. Being the typical legal normative form of dependent work from the Fordist era of capitalism, employment has evolved and continues to evolve, just like the capitalist system of production.

Key words: work, employment, slavery, Protestantism, capitalism, labor law

\section{BREVE REFRENCIA A LOS ORÍGENES DEL TRABAJO Y UN CONCEPTO GENERAL DEL MISMO}

El empleo es una forma de trabajo. Por consiguiente, y dado que para definir el empleo primero hemos de saber qué es el trabajo, resulta plausible proponer como punto de partida argumental, un concepto general de trabajo, para así ir aproximándonos al objeto de estudio.

Conceptualizando genéricamente desde una perspectiva contemporánea de la teoría de la evolución ${ }^{5}$, en esta investigación se entiende por trabajo la actividad humana, manual y/o intelectual que, trasmitiéndose de generación en generación, transforma utilitariamente el orden natural de la materia con el fin de producir satisfactores de necesidades, denominados genéricamente bienes ${ }^{6}$.

La transmisión de la experiencia productiva-laboral resulta trascendental para poder distinguir la categoría trabajo de otras actividades respeto de las cuales, eventualmemte, podría alegarse un cierto parecido de familia, por usar conocida expresión conceptual de Wittgenstein (WITTGENSTEIN [2008], pp. 87-93). Una breve incursión antropológica nos servirá para ilustrar este aspecto.

En efecto, si dejamos fuera del concepto de trabajo que se ha propuesto, el factor cualificante de "trasmisión de la experiencia", se está en condiciones de proponer que los orígenes más lejanos del trabajo podrían ser remontados incluso al pleistoceno, pues la recolección incesante de alimentos y de guijarros, que se supone ocupa a tiempo completo el variado linaje del género

\footnotetext{
Para una visión en profundidad de la evolución humana y dentro de ella, del trabajo y su significado en perspectiva antropológica: STEFoff, Rebecca. Humans: an evolutionary history. Origins and first human. New York, Estados Unidos: Marshall Cavendish Corporation, 2010; Lewin, Robert; A. Foley, Robert. Principles of human evolution. Oxford, Inglaterra: Blackwell Science Ltd, 2004; The Cambridge Encyclopedia of Human Evolution, 1992.

${ }_{6}$ Dicho concepto de trabajo también corresponde en parte a lo que Manuel Alonso Olea define como trabajo productivo, cuya característica "esencial reside en que el hombre que trabaja pone su esfuerzo teniendo como finalidad próxima la obtención a través de éste de los materiales, de los bienes económicos, de que necesita para subsistir”: Alonso Olea, Manuel. Introducción al derecho del trabajo -4a edición-. Madrid, España: Editorial Revista de Derecho Privado/Editoriales de Derecho Reunidas, 1981, p. 28. Según este autor "el trabajo objeto del derecho del trabajo, el empleo asalariado, como veremos más adelante, es el trabajo humano, productivo, libre y por cuenta ajena. La dependencia o subordinación, considerada por otros autores como característica definitoria del trabajo objeto del derecho del trabajo, la distingue como una consecuencia de la ajenidad, "porque los frutos, en el trabajo por cuenta ajena, pertenecen originariamente a persona distinta a la que trabaja, ésta se reserva una potestad de dirección o de control sobre qué frutos deben ser producidos, y cómo, cuándo y dónde deben producirse los mismos; y en caso usual hoy de frutos complejos resultado de un trabajo cooperativo, la potestad de coordinar la producción de cada trabajador con la de los restantes”, p. 47.
} 
australopitecus $^{7}$, implica un cierto reordenamiento de los materiales de la naturaleza, y por tal motivo, admitiría ser distinguida como una actividad animal que comparte algunas características del trabajo ${ }^{8}$.

Evidencias arqueológicas en las rutinas de subsistencia de una o más especies del genero australopitecus, que potencialmente indicarían que estos primates bípedos pudieron haber construido elementales utensilios mediante la técnica de entrechocar guijarros o pequeñas piedras haciéndolas estallar, son las que han sugerido esta búsqueda antropológica del trabajo en los comienzos más lejanos del hombre 9 .

En efecto, no en vano tan arcaica industria, dicen algunos, cuyos vestigios han sido encontrados en África austral en la caverna de Makapansgt, fue denominada "pebble culture", es decir, civilización de los guijarros estallados. Y puesto que además han sido descubierto vestigios de cenizas que testimonian estallamientos de guijarros por el fuego y fuegos intencionados, es que algunos antropólogos, prehistoriadores y arqueólogos se han preguntado si aquél primer proyecto de homo habilis ${ }^{10}$, pudo haber sido al mismo tiempo, un germen de proyecto de homo prometheus ${ }^{11}$.

Si bien es cierto que un hito importante en esta evolución hacia el hombre y el trabajo, acontece cuando el prehumano -el australopiteco- "coge dos guijarros para entrechocarlos el uno contra el otro, con el fin de romper uno y hacerlo más afilado o más cortante, provocando así un ángulo nuevo, vivo y cortante"12; no lo es menos que, sin embargo, el nacimiento del trabajo propiamente tal, podría ser situado en el momento en que una especie -del género homo ${ }^{13}-$ logra

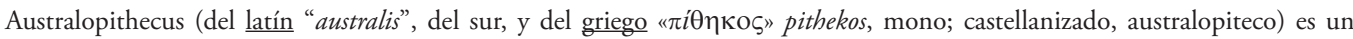
género extinto de primatres homínidos. Taxonómicamente con el término homínido se distingue a un miembro del grupo zoológico que incluye a todos los organismos, vivos o extintos, que están evolutivamente más próximos al ser humano (homo sapiens) que al chimpancé común (Pan Troglodytes). Desde el punto de vista anatómico, la característica esencial que distingue a los homínidos del resto de los primates hominoideos es la posición erguida y la locomoción bípeda obligada El australopithecus vivió en África desde hace algo más de 4 millones de años hasta hace unos 2 millones de ańos. El tamaño de su cerebro era similar al de los grandes $\underline{\text { simios }}$ actuales. Se distingue varias clases de australopithecus, a saber: Afarensis, Ghari, Africanus, Aethiopicus, Boiseis, Robustus: The Cambridge Encyclopedia of Human Evolution, 1992, op.cit. (n. 5), pp. 231-240; Rosas González, Antonio. "Pautas y procesos de evolución en el linaje humano”, en: Soler, Manuel (coord.). Evolución: la base de la biología .Madrid, España: Proyecto Sur, 2002, pp. 356-359. El género homo, al que pertenece el homo sapiens-sapiens, tendría ancestros comunes con los australopithecus: Berdichewsky, Bernardo. Antropología Social: Introducción. Una visión global de la sociedad. Santiago, Chile: LOM, 2002 , pp. 36-37. Hoy en día la evolución humana "se ve más como un arbusto desparramado que como un simple árbol genealógico, donde varias especies luchan por sobrevivir, prácticamente en cada etapa de la prehistoria” BerDichEwsky, Bernardo, op. cit., p. 37. Y además, su estudio se encuentra en la actualidad en uno de los momentos más interesantes, por el incremento del registro fósil de homínidos y el auge la investigación morfogenética donde la paleoantropología es claramente sensible. Rosas Gonzalez, Antonio, op. cit., p. 355.

Nougier, Louis-René, op. cit. (n. 1), pp.13-14-15.

Una muy reciente publicación en la prestigiosa revista Nature informa sobre el descubrimiento de evidencia de 3.39 millones de ańos atrás, descubierta en Dikika, Etiopía, del uso de herramientas para fracturar huesos y desgajar la carne de animales, incluyendo la médula de los huesos. Estas actividades se le atribuirían al Australopithecus Afarensis, pues tal especie de Australopithecus habitó esa zona, como la famosa "Lucy" (AL-288-1), cuyo esqueleto, casi completo, se conoce desde 1974. EVIDENCE for stone-tool-assisted consumption of animal tissues before 3.39 million years ago at Dikika, Ethiopia por Shannon P. McPherron, Zeresenay Alemseged; et al. Nature. Vol 466,12 August, 2010, doi: 10.1038/nature09248, pp.857-860).

10 Parece más correcto decir proyecto de homo habilis porque, tal categoría taxonómica, aunque con debate, se le atribuye a una especie de homínido distinto, que representaría un avance evolutivo respecto de los australopitecus. No sin controversia, se ha considerado el homo habilis como una especie intermedia entre el australopitecus y el homo sapiens. The Cambridge EnCyClopedia of Human Evolution, op.cit. (n. 5), p. 242. Pero el tema es muy discutido en antropología física y biológica, y sujeto a constantes e impredecibles variaciones según el descubrimiento de nuevos registros fósiles. De hecho, algunos autores tienden a considerar al homo habilis como Australopithecus Habilis: Rosas Gonzalez, Antonio, op. cit., (n. 7), p. 363.

11 Nougier, Louis-René, op. cit. (n. 1), p.15.

$12 \quad$ Ibid., p. 17. 
Marcos López Oneto / Las metamorfosis del trabajo: del trabajo al empleo

transmitir o asegurar a las generaciones futuras la experiencia o conocimiento de esas primeras prácticas o gestos sub-fabriles (choque de guijarros) de construcción de herramientas básicas ${ }^{14}$.

Vale decir, será en definitiva la transmisión de la experiencia laboral, asegurando su continuidad transgeneracional en la evolución del género homo, lo que daría verdaderamente inicio al trabajo, al hombre y a su emanación social elemental, a saber, la cultura.

El conocimiento antropológico sugiere que las especies del género homo que no logran perpetuar y complejizar su experiencia laboral, careciendo de sistemas nemotécnicos ${ }^{15}$, se pierden en las tinieblas de la prehistoria. Fue el homo sapiens-sapiens el que lograría transmitir la experiencia del trabajo, dándole continuidad y evolución a su linaje, superando la fugacidad y contingencia vital de las otras especies. De ahí que se sostenga que el trabajo está indisolublemente ligado al nacimiento del hombre que no sólo reproduce su especie, sino que conjuntamente al medio o hábitat, a través de un proceso diferenciador signado por la técnica, fenómeno que supone una base acumulativa de experiencias que se mantiene y evoluciona.

Al respecto, escribe Nougier:

"Esta transmisión es el verdadero nacimiento del trabajo. Antes, toda repetición de un gesto manual por elemental que fuese, era fruto del genio o resultado de la casualidad. Ese gesto era "un" trabajo sin ser "el" trabajo". En adelante, gracias a esa transmisión -mímica expresiva e imitativa, o primeros sonidos significativos- el trabajo se organiza. Pierde su carácter difuso, no especializado, no jerarquizado, para adoptar formas originales y diversas de trabajo, para diferenciar a los trabajadores. Las "clases" aparecen con las primeras herramientas" 16 .

También merece ser destacado que el trabajo, desde sus orígenes, es la base organizativa de todo orden social, de modo tal, que cualquier cambio en el orden laboral, genera cambios y modificaciones en la estructura global de la existencia humana. Esa es la conclusión que se puede extraer de la monumental "Historia General del Trabajo" dirigida por Louis-Henri Parias ${ }^{17}$, en la cual se estudia el trabajo desde la prehistoria del hombre hasta la civilización industrial.

Otra de las conclusiones relevantes que es posible advertir en la obra de Parias, en capítulo escrito por Nougier, es que, también desde sus orígenes, y puesto que en él afloran las diferencias manuales e intelectuales de los ejecutantes, el trabajo:

homo y los problemas y discusiones de las filogenias morfológicas, v. Rosas GonZalez, Antonio, op. cit. (n. 7), pp. 362 y ss; The Cambridge Encyclopedia of Human Evolution, op.cit. (n. 5), pp. 241-251.

14 El Bifaz, que es una herramienta lítica prehistórica de cronología muy larga. Ha sido denominado como Bifaz porque el modelo arquetípico sería una pieza de talla, generalmente, bifacial (esto es, con dos caras), de morfología almendrada y tendente a la simetría según un eje longitudinal y según un plano de aplastamiento. "La fabricación de bifaces constituye la primera revolución técnica. La segunda aparece con los nuevos procedimientos de talla en el Levallois-Musteriense, y en la producción en serie de los útiles de silex. A. Leroi-Gourhan ha mostrado concretamente la evolución de la talla del sílex y toda la importancia de esta segunda revolución técnica, que domina todo el viejo continente, en tiempos de la última glaciación Würm, hace unos 40.000 ańos". Nougier, LouisRené, op. cit. (n. 1), p. 24.

15 Sobre el significado evolutivo antropológico de la memoria y la experiencia, hitos de la cultura, André Leroi-Gourhan, etnólogo, arqueólogo e historiador, y uno de los grandes especialistas franceses en Prehistoria y Antropología, postuló en su famosa obra "El gesto y la palabra", que la memoria del hombre está exteriorizada y su continente es la colectividad étnica y que aquello, es lo que la distingue de la memoria animal: Leroi-Gourhan, Andre. El gesto y la palabra. Traducción Felipe Carrera D. Caracas, Venezuela: Ediciones de la Universidad Central de Venezuela, 1971, p. 254.

16 Nougier, Louis-René, op. cit. (n. 1), p. 18.

17 Parias, Louis-Henri (dirigida). Historia General del Trabajo. México. Tomo III. Ediciones Grijalbo, 1965. 
“crea una jerarquía social (...) rápidamente, la jerarquía de los trabajadores se enriquece (...) Así, desde el más lejano origen, brota la diversidad de las ocupaciones humanas: el que recoge, el que crea la herramienta, el que la utiliza. La organización del trabajo es pronto compleja, como son varias las condiciones del trabajo y diversas la sujeción y el género de vida de los trabajadores"18.

Por consiguiente, y dado que en su génesis plantea el problema del reparto de las tareas, el trabajo llevaría implícito un principio básico de diferenciación social por clases de trabajadores. Este fenómeno contribuirá en algún momento a generar el problema del reparto de los frutos del trabajo y a la estructuración de la sociedad en clases o grupos sociales.

Pues bien, sobre la base de las ideas anteriormente expuestas, estamos en condiciones entonces de profundinzar conceptualmente, y proponer que, el trabajo, es una relación social fundante de lo humano, cuyo desenvolvimiento y desarrollo, endógenamente, ha generado diferenciaciones sociales; fenómeno que ha influido en la estructura de las sociedades en términos tales, que es posible sugerir que un cambio en la relación social de trabajo generaría variaciones en la estructura global de la sociedad por ser aquella un principio diferenciador básico ${ }^{19}$; lo cual no importa clausurar la posibilidad teórica de pensar que la relación entre trabajo y estructura de la sociedad, también pueda ser dialéctica en el sentido que ambos fenómenos no se desarrollan aisladamente, sino operan influenciándose mutua y recíprocamente ${ }^{20}$.

18 Nougier, Louis-René, op. cit. (n. 1), p.19. A propósito del trabajo en la sociedad primitiva, y reflexionando a partir Krader, Berdichewsky, escribe: "La relación de trabajo en la sociedad tribal es directa e inmediata. Las gentes trabajan los unos para otros y la producción de bienes de uso no está separada de los bienes para intercambio. La división del trabajo, en virtud de las diferencias de sexo, edad, salud o fuerza, en este contexto no es, por lo tanto, una división mediata, social del trabajo, sino que una división del trabajo inmediata, natural, directa”. Berdichewsky, Bernardo, op. cit. (n. 7), p. 147.

19 Merece destacarse que, con importantes fundamentos etnográficos, Marvin Harris (1927-2001), en un intento por dotar a la antropología de una estrategia de explicación materialista cultural de la evolución del hombre, propone considerar el principio del determinismo tecnoecológico y tecnoeconómico. "Este principio sostiene que tecnologías similares aplicadas a medios similares tienden a producir una organización del trabajo similar, tanto en la producción como en la distribución, y ésta a su vez agrupamientos sociales de tipo similar, que justifican y coordinan sus actividades recurriendo a sistemas similares de valores y creencias" HaRRIS, Marvin. El desarrollo de la teoría antropológica. Una historia de las teorias de la cultura - 16a edición -. Traducción Ramón Valdés del Toro Madrid, España: Editorial Siglo XXI, 2008, p. 3.

20 El esclarecimiento y fundamentación de la dialéctica del trabajo, supera los límites trazados a estas notas de lectura. Sin embargo, hacemos presente que nos inclinamos más por una fundamentación general desde la vertiente del entendimiento de la dialéctica como síntesis de opuestos Abbagnano, Nicola. Diccionario de Filosofía. $4^{a}$ edición en español 1a reimp, traducción de José Estebán Calderón y Alfredo N. Galleti, actualizado por Giovanni Fornero. México: Fondo de Cultura Económica, 2007, p. 298. Esta premisa sugiere que la diferenciación del trabajo contribuye a la diferenciación global de la estructura social que no puede sino ser también normativa, pues lo normativo no está fuera de la sociedad. El ordenamiento jurídico, dice Alonso Olea, citando a M. van de Ven, en suma, "forma parte de la totalidad de la cultura; no es un plano superimpuesto sobre la realidad social" Alonso Olea, Manuel, op. cit. (n. 6), p. 9. Este fenómeno circular entre realidad y norma, esta dialéctica entre trabajo y normatividad, queda claramente expuesta por Alonso Olea cuando dice que el derecho basándose en la realidad, también la modula, cuestión que puede apreciarse "en la transformación social operada sobre el esclavo transformándolo en persona-sujeto desde un estadio previo de cosa objeto" Ibid., p.7. Puntualiza: “(...) porque el Derecho no es una superestrucutura que se contente con dar forma a una materia que le venga dada (...) el Derecho es, en sí mismo, una fuerza social operante que modula los cambios, los acelera o los retrasa...” Ibid., p. 8. Entonces bien, "aun admitido que la norma reposa en la realidad (...) su regulación refluye sobre ésta, modulándola y robusteciéndola, o debilitándola, integrándose en ella en un factum de realidad jurídica normada cuyos dos elementos son ya inseparables” Ibid., p. 9. 


\section{LAS METAMORFOSIS DEL TRABAJO}

Se ha mostrado que el trabajo es una especie de constante antropológica, y que su historia es tan antigua como la historia de la humanidad. En el decurso de este largo proceso, el trabajo ha conocido diversas formas o construcciones sociales, en términos tales que es posible describirlo, a grandes rasgos, como una metamorfosis o viaje desde la esclavitud o periferia, hacia la libertad o centralidad valórica-social.

Asimismo, conviene que desde ya establezcamos que el foco de esta reconstrucción teórica estará centrado no en el trabajo en general, sino que en una especie de trabajo, a saber: el denominado trabajo productivo por cuenta ajena, dependiente o subordinado (y no en el denominado trabajo autónomo, por ser sólo el primero, objeto del Derecho del Trabajo).

A modo de breve aclaración conceptual, debe tenerse presente que la distinción metodológica más general de trabajo productivo ${ }^{21}$ que utilizamos en el campo científico del Derecho del Trabajo, es aquella que separa el trabajo por cuenta propia (trabajo autónomo) del trabajo por cuenta ajena, según quien sea el sujeto que se apropia originariamente de los frutos del mismo.

En el trabajo por cuenta propia, cuyo modelo típico es el artesanado, es al propio trabajador a quien se le atribuyen originariamente los frutos; a diferencia del trabajo por cuenta ajena, en donde un tercero es el que, desde el momento mismo de la producción, se hace dueño de aqué$1 \operatorname{los}^{22}$.

El trabajo por cuenta ajena, puede ser forzoso o libre. Habiendo prevalecido el trabajo por cuenta ajena forzoso -la esclavitud-, después de un largo y complejo proceso histórico, distinguido como conquista civilizadora de la humanidad, el trabajo ha devenido en libre, siendo la figura del empleo asalariado, su expresión normativa típica.

La revisión sintética de este íter resulta trascendental para comprender la importancia del empleo como una construcción normativa superadora de todas las otras formas históricas de trabajo dependiente que han existido, pues en el empleo se plasmarán las bases para una concepción que eleva la facticidad del trabajo por cuenta ajena, a derecho fundamental en una sociedad organizada como Estado de Derecho.

\subsection{LA ESCLAVITUD Y OTRAS FORMAS PERIFÉRICAS DE TRABAJO}

Sobre la esclavitud se ha escrito bastante y desde diversas perspectivas ${ }^{23}$. Para los efectos en esta reconstrucción histórico-conceptual, lo que interesa destacar sobre el tema es que, en gene$\mathrm{ral}^{24}$, para el mundo civilizado antiguo, Grecia y Roma, el trabajo es considerado algo indigno, pe-

\footnotetext{
21 Por oposición al trabajo entendido como actividad separada de la finalidad de subsistencia y para diferenciarlo de otras actividades asociadas al tiempo libre, como las distracciones, esparcimientos o acciones solidarias. Al respecto dice Alonso Olea: “(...) mientras que el trabajo productivo está presidido por una finalidad - procurar la subsistencia de quien trabaja-y en tal sentido es una actividad medial o instrumental, o no es un fin en sí mismo, el juego es una actividad por completo libre, sin finalidad que la condicione; que se juega por jugar, mientras no se trabaja por trabajar, y si se trabaja por trabajar, se está en realidad jugando" Alonso Olea, Manuel, op. cit. (n. 6), p. 27.

22 Alonso Olea, Manuel., op. cit. (n. 6), p. 34.

23 Por supuesto que en la ya citada "Historia General del Trabajo" de Louis-Henry Parias se le trata con detalle histórico en el tomo I, p. 15. Por otra parte, el mismo Alonso Olea en su Introducción al Derecho del Trabajo le dedica varias páginas, citando una muy completa bibliografía sobre el tema. Véase. Alonso OleA, Manuel., op. cit. (n. 6), pp. 99-122. Otra interesante presentación del tema en Borrajo Dacruz, Efrén. Introducción al derecho del trabajo -19a edición-. Madrid, España: Tecnos, 2010, pp. 88-92.

24 En general se dice, porque tanto en Grecia como en Roma existió paralelamente a la esclavitud, un tipo de trabajo manual, autónomo y libre, a saber: el de los artesanos, asociados, en el caso de Roma, en los collegia. También se conoció en Roma la
} 
noso, contrario a la esencia humana y opuesto a la libertad ${ }^{25}$. Son conocidas las fundamentaciones sobre la legitimidad de la esclavitud que en la Grecia clásica hacen Aristóteles ${ }^{26}$ e incluso quizás hasta el mismo Platón ${ }^{27}$; o Cicerón y Séneca, en Roma.

El trabajo es lo propio de los esclavos. Así es como en la Grecia clásica, por ejemplo, el hombre que decidía cultivar sus propias tierras era considerado "un misántropo, un personaje extraño" ${ }^{28}$ y la pobreza extrema se caracterizaba justamente "por no poseer un esclavo al menos" 29.

Decíamos que el trabajo era la actividad propia de los esclavos. Se trataba de una actividad despreciable, indigna y lejana incluso al concepto de hombre y ciudadano ${ }^{30}$. Como es conocido, el espacio de realización de la ciudadanía era el ágora, en donde filosofar, contemplar, discutir, politizar, constituían las actividades propias de tal condición jurídica, puesto que los hombres libres participaban de la koinomía politiké, claramente diferenciada de la producción material de la sociedad, la chrematiské, espacio reservado para el trabajo y la esclavitud ${ }^{31}$.

Porque para Grecia y Roma clásicas el trabajo manual es una actividad que corrompe al hombre, toda vez que mezcla el alma con la materia. Cicerón, en De Officiis, “definió el trabajo de los artesanos como actividad sucia y el trabajo asalariado como actividad de los esclavos ("ipsa merces est auctoramentum servitutid"), criticando particularmente la práctica creciente de los jornaleros" 32 .

Una esclarecedora perspectiva sobre el tema, la proporciona Hannah Arendt, cuando escribe que la esclavitud en el mundo antiguo, "aunque no en los últimos tiempos, no era un recurso para obtener trabajo barato o un instrumento de explotación en beneficio de los dueños, sino más

servidumbre, el colonato y especies arcaicas de trabajo asalariado. Pero la esclavitud era la base material principal de la estructura económica de dichas sociedades. Para más detalles, véase Montoya Melgar, Alfredo. Derecho del Trabajo - 29a edición -. Madrid, España: Tecnos, 2008, p. 78; Cabanellas de Torres, Guillermo. Compendio de Derecho Laboral - 3a edición-. Buenos Aires, Argentina: Editorial Heliastra, 2001, p. 78; Alonso García, Manuel. Derecho del Trabajo. Barcelona, España: Bosh Editor, 1960, pp. 17-18; Walker Linares, Francisco. Nociones elementales de derecho del trabajo. Santiago, Chile: Editorial Nascimiento, 1957, pp. $25-26$.

25 Alonso Garcia, op. cit. (n. 24), p. 18.

26 Aristóteles. op. cit., (n. 2), pp.189-207.

27 Platón. "Las leyes, o de la Legislación”, en: ÉL mismo. Obras completas. Madrid, España: Aguilar, 1966, p. 1518. Sin embargo, y puesto que, a diferencia de Aristóteles, en sus obras Platón no formula una posición explícita en defensa de la esclavitud, sino sólo algunas referencias, no es del todo pacífico "si existe o no la esclavitud en la ciudad ideal diseñada en "La República", Véase. Velasquez, Oscar. ¿Hay esclavos en la ciudad platónica?, en: DiadOKHE, Universidad Diego Portales, <En línea>. [Consulta 14 enero 2014]. Disponible en World Wide Web: <http://www.diadokhe.cl/media/platonica/politeia_c.pdf >. Estas referencias no categóricas de Platón que han dado pie al debate se encuentran en la República. Platón, "La República”, en: Platón., op. cit. (n. 27), pp. 741743-838. Con todo, resulta no del todo arriesgado afirmar que la toleraba o asumía como lo haría cualquier ciudadano griego de la época, según puede apreciarse en cita que ya hemos hecho a "Las Leyes".

28 Alonso Olea, Manuel., op. cit. (n. 6), p. 105.

29 Ibid., p.105.

30 El esclavo estaba completamente indignificado y reducido a cosa semoviente, incapaz de relaciones jurídicas qua domino sobre objeto alguno, incluidos, por cierto, los frutos de su trabajo: Alonso Olea, Manuel. "Introducción al derecho del trabajo", op. cit. p. 107). Al respecto, una famosa cita de Gayo recordada por Alonso Olea: "No adquirimos solamente por nosotros mismos, sino también por aquellos que están bajo nuestra "potestas", bajo nuestra "manus" o "in mancipio"; así como también por los esclavos cuyo usufructo tenemos y por los hombres libres y esclavos que poseamos de buena fe". Gayo. Institutas. Traducción Alfredo di Pietro. Buenos Aires, Argentina: Abeledo-Perrot, 1997, p. 253.

31 Köhler, Holm-Detlev; Martín, Antonio. Manual de la sociología del trabajo y de las relaciones laborales. Madrid, España: Delta Publicaciones, 2005, p. 11.

32 Ibid., p. 11. 
Marcos López Oneto / Las metamorfosis del trabajo: del trabajo al empleo

bien el intento de excluir la labor de las condiciones de vida de los hombres. Lo que los hombres compartían con las otras formas de vida animal no se consideraba humano"33.

En síntesis, para estas culturas fundadoras del mundo occidental, el trabajo es una actividad degradante y por lo mismo, periférica desde un punto de vista valórico, pues la centralidad ética estará puesta en otras actividades consideradas propias del hombre (filosofar, ir a la guerra, cultivar las artes, la política, el deporte). Por consiguiente, el eje de las relaciones sociales que permiten participar del bienestar y de la movilidad social no son las derivadas del trabajo productivo. Por estos fundamentos, se ha sostenido que en el mundo greco-romano, el trabajo era una actividad situada en los contornos o márgenes de la producción valórica ${ }^{34}$.

Se ha comprobado que la esclavitud fue evolucionando conjuntamente con la caída del Imperio Romano. Con el paso del tiempo, esta evolución se concretará, básicamente, en tres formas de trabajo periférico, a saber: la servidumbre de la gleba, el colonato y el vasallaje $\mathrm{e}^{35}$. Estas diversas formas de trabajo todavía se caracterizan por la involuntariedad pero, sin embargo, en ellas poco a poco comienza a ser sustituida la figura del esclavo por la del sirviente, al cual se le reconoce ya, y aunque precariamente, la calidad de sujeto de algunas especies de relaciones jurídicas $^{36}$. Pero con todo, sigue siendo trabajo periférico, por cuanto se valora como una actividad subalterna y quienes la ejercen, se encuentran bloqueados e inmovilizados socialmente.

\subsection{TRANSICIÓN HACIA EL EMPleO (Y/O TRABAJO ASALARIADO)}

Es posible remontar el inicio del complejo proceso de transición hacia el trabajo libre por cuenta ajena, regulado jurídicamente y en función del mercado de trabajo (esto es, el empleo), hasta los albores de la edad media. Este proceso gira en torno a la ciudad medieval que, "como unidad administrativa y económica autónoma, situada fuera del ámbito del señor feudal, comienza a generalizarse en Occidente como institución a partir del siglo XI (si se salva como excepción de mayor antigüedad la "paulatina revitalización de la vida urbana" en el-Andalus quizá desde el siglo IX)" 37 .

Porque en efecto, y como ha dicho Max Weber, la ciudad medieval significará "una enorme innovación, revolucionaria" porque "rompe con el derecho señorial" y por tanto, "es un lugar de ascenso de la servidumbre a la libertad" 38 . O como desde otra perspectiva ha enseñado Alonso

\footnotetext{
Arendt, Hannah, op. cit. (n. 4), p. 100.

34 Köhler, Holm-Detlev; Martín, Antonio, op. cit. (n. 31), p.11.

35 Cabanellas de Torres, Guillermo, op. cit. (n. 24), pp. 79-81.

36 Dicha evolución reconoce matices y etapas, imposibles de abordar en estas notas. Para una visión en profundidad AlONSO OleA, Manuel., op. cit. (n. 6), pp. 99-149.

37 Ibid., p. 151. En nota $\mathrm{N}^{\circ} 285$ de su Introducción al Derecho del Trabajo, Alonso Olea refiere que "Córdoba era, a comienzos del siglo XI, quizá ya desde el siglo X, una ciudad de medio millón de almas...la mayor ciudad de Occidente”, según SáNCHez Albornoz, C. La España Musulmana - 4a edición -. Vol. I. Madrid, España: 1974, p. 434.

38 Citado por Alonso Olea, Manuel., op. cit. (n. 6), p. 156. Por otra parte, Dawson también ha escrito sobre el conjunto de cambios de largo alcance que, en la vida intelectual de la sociedad occidental y en las tradiciones de la educación, significó la aparición de la ciudad medieval y las primeras Universidades, caracterizados en la última década del siglo XI y en las dos primeras del XII, por una notable renovación de la cultura y la actividad literaria, DAwson, Christopher. Historia de la cultura cristiana, 2a edición, México: FCE, 2006, pp. 277-298. Berman profundiza el estudio de dichos cambios acontecidos a finales del siglo XI y comienzos del XII, e informa que en cada país de Occidente se crearon tribunales profesionales, un cuerpo de legislación, una profesión jurídica, una bibliografía jurídica, una "ciencia del derecho" y que, por cierto, el impulso básico para este desarrollo provino de la Revolución Papal declarada en 1075 por el papa Gregorio VII al Emperador Enrique IV, con sus famosas “Dictatus Papae”, mediante el cual propugnó la primacía papal sobre toda la iglesia de Occidente y de la independencia de ella de todo control secular. Berman postula que así como la Revolución papal dio a luz al moderno Estado occidental, también generó "los modernos sistemas jurídicos occidentales,
} 
Olea, "el morador de la ciudad, -salvo el esclavo o siervo personal, o del servicio de la casa, normalmente de raza o religión distinta, capturado o comprado- es libre, en el estricto sentido de que no se encuentra ligado a otras personas por relaciones de esclavitud o servidumbre" ${ }^{39}$. Luego, cuando intercambia servicios personales por cuenta ajena, lo hace desde la libertad jurídica de que goza. Los frutos de ese trabajo serán atribuidos a un tercero en virtud de un pacto que precede a la producción de los mismos, delineándose los contornos del contrato de trabajo.

El cambio radical entre la esclavitud y el trabajo libre, puede ser descrito jurídicamente así: mientras que en el primer caso, el título jurídico de atribución de los frutos del trabajo es el dominio del amo sobre el esclavo; en el trabajo libre, en cambio, dicho título, es el contrato (primero civil, y luego, con el siglo XX, laboral)

Pero la evolución y desarrollo de este proceso jurídico que parte en la esclavitud y desemboca en el trabajo libre a comienzos de la revolución industrial, es muy complejo y lleno de matices que, por la naturaleza de la presente investigación, no se abordarán en su totalidad.

\subsubsection{Concepción judeocristiana medieval del trabajo}

Manteniéndose con una tenue vitalidad hasta la modernidad, el mundo judeocristiano medieval genera una concepción del trabajo que es ambivalente, pues por momentos históricos lo considerará un castigo, y en otros períodos, un camino de salvación y autorrealización espiritual, actividad digna y respetable $e^{40}$.

En la tradición judeo-cristiana, el trabajo junto con la mortalidad, son los castigos que Dios impone a Adán, Eva y sus descendientes, por haber infringido el mandato de prohibición de alimentarse de los frutos del árbol del conocimiento del bien y del mal.

El razonamiento teológico dice que, si el único creador del universo es Dios, el hombre, ser finito y limitado, no puede serlo. No pudiendo, en consecuencia, el trabajo -actividad humanaser acto de creación, a lo más, en esta primera concepción medieval, admitirá una caracterización de acto de renovación del mundo. Y dado por otra parte que el trabajo es un castigo a consecuencia del pecado original, en la cotidianidad del hombre, pasará éste a ser una actividad aburrida y tortuosa.

En la temprana edad media, cuando ya el cristianismo se convierte en la religión dominante de occidente, esta concepción del trabajo como algo tortuoso, se consolida.

La etimología de la palabra trabajo expresaría aquél sentido. Proviene del latín tripalium, que designa un instrumento de tortura. Sin embargo, como ha resaltado Vatin:

"esto es cierto sólo a medias, ya que en principio el tripalium es sólo un banal "trípode" (instrumento con tres pies), que puede servir sin duda como "soporte" (en sentido literal y metafórico) para la tortura, pero también y fundamentalmente para sujetar a los animales

el primero de los cuales fue el sistema moderno de derecho canónico". En dicho proceso, sin duda que la ciudad de Bolonia, en el norte de Italia, ocupa un rol preponderante en la enseñanza del derecho, con figuras trascendentales para la historia de derecho como Irnerio. Pero en París también se da inicio a este proceso jurídico intelectual, con figuras como Pedro Abelardo (1079-1142). "En Oxford, Vacario, graduado en Bolonia, profesó el derecho romano a mediados del siglo XII, aunque al parecer una facultad de derecho, como tal, no fue establecida en Oxford (y otra en Cambridge) hasta el siglo siguiente". Berman, Harold. La formación de la tradición jurídica de Occidente $-1^{\mathrm{a}}$ edición-. Traducción Mónica Utrilla de Neira. México: Fondo de Cultura Económica, 2001, p. 137.

39 Alonso Olea, Manuel., op. cit. (n. 6), pp. 156-157.

40 KöHler, Holm-Detlev; Martín, Antonio, op. cit. (n. 31), p. 11. 
Marcos López Oneto / Las metamorfosis del trabajo: del trabajo al empleo

grandes cuando se los cura o se los marca. Así, el "trabajo" designó en primer lugar, en un sentido técnico que se mantuvo hasta nuestros días, este inocente instrumento del criador y del herrero. Es por medio del verbo (tripaliere: hacer sufrir en el tripalium) y no por medio del sustantivo que apareció el sentido moderno de pena" ${ }^{31}$.

Serán las nuevas órdenes monásticas de la Edad Media Tardía (siglo XII) las que recuperarán la concepción del trabajo como posibilidad de salvación. El argumento es el siguiente: si el cumplimiento de la pena divina mediante el trabajo es condición de salvación, pues quien la cumpla, podrá alcanzar la gloria eterna. Luego, no puede ser una actividad secundaria o subalterna (valóricamente entendida). El trabajo es una actividad buena, noble y virtuosa porque salva al hombre.

Considérese, por ejemplo, en la trascendencia que tuvieron las normas de San Agustín; las reglas de los Benedictinos (otiositas inimica est animae -el ocio es un peligro para el alma) para la fundación de la ética del trabajo monástico, ora et labora ${ }^{42}$. Y si el ocio es un peligro para el alma, el vagabundeo y la mendicidad serán elevados a la categoría social de encarnación de tal espíritu, al extremo que serán penalizados ${ }^{43}$.

Esta revalorización del trabajo, que ya no lo distingue principalmente como una pena, sino como camino de salvación, se expande horizontalmente también al resto de la sociedad medieval, irradiándola comunicacionalmente, en la cual pronto el ocio y el vagabundeo, ganarán desprestigio.

Así es como el trabajo, saliendo de la periferia valórica de la sociedad, comienza a ocupar un lugar en ella, transformándose lentamente en factor de movilidad y en eje de la construcción de

41 Vatin, Francois. Trabajo, ciencias y sociedad. Ensayos de sociología y epistemología del trabajo. <En línea>. Buenos Aires, Argentina: Trabajo y Sociedad, CEIL-PIETTE, Lumen-Humanitas, 2004. [Consulta: 20 febrero 2012] Disponible en World Wide Web: $<$ http://www.ceil-piette.gov.ar/docpub/libros/trcs.html\#intr> Por otra parte, en la lengua francesa, escribe Supiot, el significado inicial de la palabra designa el sufrimiento que ha de soportar la mujer en el parto. Este sentido ginecológico es el único que habría existido en la lengua gala hasta el siglo XVI. Supıot, Alain. Crítica del derecho del trabajo. Madrid, España: Ministerio del Trabajo y Asuntos Sociales, p. 19.

42 Köhler, Holm-Detlev; Martín, Antonio, op. cit. (n. 31), p. 13. En efecto, Benito de Nursia escribió a principios del siglo

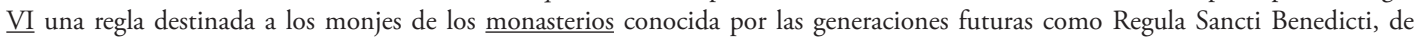
73 capítulos, algunos ańadidos y modificados después por sus seguidores. Esta regla benedictina será acogida por la mayoría de los monasterios fundados durante la Edad Media. El principal mandato es el ora et labora, con una especial atención a la regulación del horario. Un edición de la Regla de San Benito, puede consultarse en: <En línea>. [Consulta: 2 marzo 2014]. Disponible en World Wide Web: <http://www.sbenito.org.ar/regla/rb.htm>.

43 Ya Platón (Platón, op. cit. (n. 27), p. 1518) condenaba la mendicidad en su ciudad ideal. Castel, en un profundo análisis sociológico, escribe que a mediados del siglo XIV se inicia en Europa una persecución al vagabundo Castells, Robert. Las metamorfosis de la cuestión social. Una crónica del salariado. Buenos Aires, Argentina: Paidós, traducción Jorge Piatigorsky, 2009, pp. 71-108. Más aún, se dictan leyes para obligar a trabajar a las personas. Entre muchos ejemplos, cita el caso de Eduardo III, Rey de Inglaterra, que en 1349 promulga la ordenanza conocida como "Estatuto de los Trabajadores" (Statutum serventibus, Statute of Labourers) que obligaba a trabajar a los súbditos, hombres o mujeres, menores de 60 ańos, que no poseyeran bienes suficientes para subsistir y que no estuvieren al servicio de nadie (not serving any other). En caso de infracción a estos deberes, se imponían severas penas que incluso, podían llegar a imponer verdaderos estados fácticos de esclavitud. En la Península Ibérica, Alfonso IV de Portugal, en 1349, las Cortes de Aragón en 1349 y 1350, y las de Castilla en 1359, establecieron salarios máximos, y la prohibición del desplazamiento para buscar empleo y la represión del vagabundeo. Ibid., p.72. En Francia surge el entendimiento del vagabundo como "inútil para el mundo". Ibid., p.90. Y son criminalizados. En 1767 se abrieron los "depósitos de mendicidad”. Una revisión de la actas de un depósito de vagabundos de Soissons, en el final del antiguo régimen que reveló que más del 80\% de los vagabundos eran en realidad desocupados (obreros manuales y agrícolas) y que menos del $10 \%$ correspondía vagabundos verdaderos, es decir, gente que no tenía ningún interés en trabajar prefiriendo la mendicidad. Ibid., p. 97. A juicio de Castel, "la cuestión del vagabundeo consiste de hecho en la manera en que se formula y a la vez se oculta la cuestión social en la sociedad preindustrial”. Ibid., p. 108. 
la imagen positiva que la sociedad tiene de sí misma. No tardará mucho, entonces, el trabajo en ser concebido como una síntesis entre camino de salvación y dignificación de lo humano.

Pero con todo, la valorización del trabajo será un proceso lento y de desarrollo asimétrico en el plano de Europa y por rebote, y con sus evidentes diferencias, asimetrías y particularidades, en el Nuevo Mundo ${ }^{44}$; pues la inercia de la concepción del trabajo como algo degradande, no perderá impulso sino hasta la revolución industrial. Testimonio de esta compleja dinámica, en cuanto a la lenta y paulatina disolvencia histórica de la indignidad del trabajo, nos la proporciona Charles Loyseau (1566, Nogent-elRey-1627, París), quien en su "Traité des ordres et simples dignites", publicado en París en 1610, escribía que "los artesanos, o gente de oficio, son quienes ejercen las artes mecánicas y, de hecho, llamamos comúnmente mecánico a lo que es vil y abyecto. Los artesanos, siendo propiamente mecánicos, tienen reputación de personas viles" ${ }^{45}$.

\subsubsection{La concepción protestante del trabajo}

El proceso de centralización valórica del trabajo de la edad media tardía, adquiere perfiles más definidos con la reforma protestante que lo convertirá en una actividad ascética, fuente de autorrealización del hombre y afianzamiento de la predestinación o de la seguridad en la salvación divina (certitudo salutis). La reforma protestante reconoce dos vertientes: luteranismo, que es la que le da inicio; y la vertiente calvinista, que es distinguida como una continuación más radical.

\subsubsection{Luteranismo}

En "La ética protestante y el espíritu del capitalismo", Max Weber escribe que la auri sacra fames 46 "es tan antigua como la historia de la humanidad" y que en caso alguno representa la mentalidad o el ethos de lo que denomina espíritu del capitalismo. Todo lo contrario, la auri sacra fames, es más "propio de las culturas precapitalistas y de las mentalidades aventureras, constituyendo uno de los más potentes obstáculos internos con los que hubo de luchar en todas partes la adaptación del hombre a los supuestos de una economía capitalista y burguesa ordenada" ${ }^{47}$. Porque el espíritu capitalista comienza a distinguirse cuando el trabajo se práctica como un "absoluto fin en sí, como profesión" 48 . Al respecto Weber cita el caso de la repulsión y la persecución de que fueron objeto las trabajadores metodistas por parte de sus compañeros de labores en el siglo XVIII, por su docilidad o gran capacidad de trabajo.

Pues bien, la tesis que Weber se propone demostrar es que "el espíritu del ascetismo cristiano fue quien engendró uno de los elementos constitutivos del moderno espíritu capitalista, y no

\footnotetext{
44 Para una reconstrucción histórica del trabajo en la América precolombina y colonial: Cabanellas de Torres, Guillermo, op. cit. (n. 24), pp. 83-105; Walker Linares, Francisco, op. cit. (n. 24), pp. 35-41.Para una perspectiva del trabajo en Chile desde la colonia hasta 1973, véase Rojas Flores, Alberto. Los trabajadores desde la colonia hasta 1973. <En línea>. [Consulta: 2 noviembre 2013]. Disponible en World Wide Web: <http://www.bibliotecaobrera.cl/wp-content/uploads/2008/10/los-trabajadores-chilenos-desde-lacolonia-hasta-1973-jorge-rojas-flores.pdf>.

45 Citado de primera fuente por Castel, Robert. op. cit. (n. 43), p. 129. Hemos podido consultar una edición en inglés del texto de Loyseau: Loyseau, Charles. A Treatise of Orders and Plain Dignities. New York, Estaods Unidos: Cambridge University Press, 2007.

46 Detestable hambre de oro. Expresa el desmesurado deseo humano de bienes materiales, el execrable vicio de la avaricia. "Auri sacra fames" aparece en los versos 56 y 57 del libro III de la Eneida. Siglos después el Marqués de Santillana en su obra Doctrinal de Privados, lo traduciría como “;Fambre de oro raviosa?". V. <En línea>. [Consulta: 21 abril 2014]. Disponible en World Wide Web: <http://www.cervantesvirtual.com/servlet/SirveObras/57937519116805384122202/p0000001.htm\#I_0_>.

47 Weber, Max. La ética protestante y el espíritu del capitalismo. $3^{a}$ reimpresión. Traducción Luis Legas Lacambra. México: Fondo de Cultura Económica, 2008, p. 106.

48 Ibid., p. 109.
} 
Marcos López Oneto / Las metamorfosis del trabajo: del trabajo al empleo

sólo de éste, sino de la misma civilización moderna: la racionalización de la conducción de vida (Lebensführung) sobre la base de la idea profesional"49.

El espíritu ascético cristiano es identificado por Weber, primero, en el que se forma históricamente con el Reformismo de Lutero y luego, en el que vendrá con Juan Calvino.

La concepción Luterana del trabajo se sintetiza en la palabra alemana Berufy en la inglesa Calling. Se trata de la idea del trabajo como profesión; de llamamiento interno al deber; de posición en la vida o de vocación. Según Weber, el sentido de la palabra Beruf nació de la traducción luterana de la Biblia ${ }^{50}$, "no existiendo precedentes semióticos similares ni en la Edad Media, ni en la antigüedad o en el helenismo de la última época, para esa estimación del trabajo cotidiano en el mundo que implica esta idea de profesión (...) en sentir como un deber el cumplimiento de la tarea profesional en el mundo" ${ }^{51}$.

En la concepción Luterana, el trabajo es parte del orden natural, como comer o beber, no susceptible de valoración ética, dice Weber ${ }^{52}$. Luego, si el trabajo es parte de la creación divina, entonces el hombre debe ejecutarlo como parte de su naturaleza intrínseca; como parte de su ser; como una profesión, como una forma de justificarse ante Dios. Al trabajar, pues, el hombre realiza su esencia; participa de la creación y, al hacerlo, adquiere una dimensión que lo coloca en la senda de Dios.

Lutero rechaza la vida ascética monástica y la considera producto de un desamor egoísta, que sustrae al hombre de los deberes para con Dios. Y opone a la vida ascética monástica, el trabajo profesional como manifestación del amor al prójimo.

Lo propio y específico de la Reforma, escribe Weber, en contraste con la concepción católica, es haber acentuado el matiz ético y aumentado la primacía religiosa concedida en el mundo racionalizado en profesión ${ }^{53}$. En tanto profesión (Beruf), el trabajo es un envío de Dios al hombre, ante lo cual éste debe allanarse. Por esta razón, finalmente, en la concepción luterana, el trabajo es una misión impuesta por Dios al hombre. Y las riquezas materiales que se logran con ocasión de él, no son un fin en sí mismas, pues el fin no es otro que la salvación del alma.

\subsubsection{Calvinismo}

El dogma clave del calvinismo es la idea de la predestinación del alma. En efecto, según Calvino, Dios, mediante decretum horribile, decide la salvación de unos y la muerte eterna de otros. No existe voluntad humana capaz de eludir tal mandato. A tal circunstancia teológica adiciónesele que los designios de Dios son incognoscibles para el hombre, y el hombre, por tanto, jamás tendrá certeza de ser elegido (certitudo salutis). Frente a esta dura e implacable realidad teológica, el calvinista postula su propia salvación o más bien, su propia señal de estar en el camino de la salvación, a través de los logros económicos obtenidos del metódico e incesante trabajo: "único modo de ahuyentar la duda religiosa y de obtener la seguridad del propio estado de gracia” ${ }^{54}$. Dícese así, que

\footnotetext{
49 Ibid., p. 285.

50 Weber remonta incluso el sentido de la expresión a la obra de Jesús Sirach (11, 20 y 21). Cabe tener presente la formidable investigación filológica que Weber realiza sobre el tema y la cual queda registrada en las notas a pie de página del capítulo III de la Primera Parte, "Concepción Luterana de la Vocación. Tema de nuestra investigación”, v. Weber, Max, op. cit. (n. 47), pp. 129-152.

51 Ibid., pp. 134-136.

$52 \quad$ Ibid., p. 137.

53 Weber, Max, op. cit. (n. 47), p.141.

54 Ibid., p. 180.
} 
el calvinismo "promueve el definitivo desencantamiento del mundo, pues elimina todo lo sobrenatural o mágico en la idea de salvación del hombre. No hay magia, sino sólo trabajo" 55 .

Para el Puritanismo inglés, fuertemente influenciado por el calvinismo, el trabajo se transforma en un fin absoluto de la vida. El principio paulino "quien no trabaja que no coma" se aplica incondicionalmente a todos; "y quien siente disgusto en el trabajo, pues entonces ha de saber que aquel sentimiento, es una prueba irrefutable de que le falta el estado gracia" ${ }^{\text {. }}$.

Dios no exige trabajar por trabajar, sino trabajo racional en la profesión. Explica Weber que en "este carácter metódico de la ascesis profesional radica el factor decisivo de la idea puritana de profesión, no (como en Lutero) en el conformarse con lo que, por disposición divina, le toca a uno en suerte" ${ }^{25}$.

Así como los frutos del trabajo, indicio de salvación, no deben ser derrochados o malgastados, sino que reinvertidos; el tiempo no debe ser dilapidado, sino que aprovechado, segundo a segundo, de manera ordenada y metódica, en trabajar en la profesión. ¿Pero cómo saber cuál es la profesión que Dios nos ha asignado? Pues no de otra forma que tomando como profesión aquél oficio que nos proporciona más riqueza. Escoger otro camino, "es poner obstáculos a vuestra vocación (calling) y os negáis a ser administradores (stewards) de Dios"58.

Desde otra perspectiva, ALONSO GARCÍA repara que la dualidad predestinados y elegidos se traduce en una significación histórica-concreta, a la existente entre capitalistas y proletarios. Los primeros, son los elegidos para salvación, pues su éxito, así lo prueba. A los proletarios, en cambio, su pobreza los condena a la muerte eterna ${ }^{59}$. Contra esta concepción de un orden natural inmodificable, Marx opondrá su célebre frase "la religión es el opio del pueblo" ${ }^{60}$ y su undécima tesis sobre Feuerbach: "Los filósofos no han hecho más que interpretar de diversos modos el mundo, pero de lo que se trata es de transformarlo" ${ }^{1}$.

\footnotetext{
55 Ibid., pp. 167-168. Resulta interesante documentar que, quizás como nadie, el sentimiento de soledad existencial o desencantamiento del mundo que generó el protestantismo, ha sido magistralmente representado por Ingmar Bergman en el film "Luz de Invierno" (también traducida como "Los Comulgantes"), 1962, en el cual el Pastor Tomás Ericsson se enfrenta al silencio de Dios y a un mundo sin eco espiritual.

56 Weber, Max, op. cit. (n. 47), p. 250.

57 Ibid., p. 254.

58 Ibid., p. 256.

59 Alonso Olea, Manuel. Derecho del Trabajo. Barcelona, Espańa: José Ma Bosh Editor, 1960, p. 22.

60 La frase fue escrita por Marx en un artículo introductorio a la Filosofía del Derecho de Hegel, en 1844. Una versión del artículo en: Hegel, Guillermo Federico. Filosofía del Derecho. Introducción de Carlos Marx, 4a edición, traducción Angélica Mendoza de Montero, de la versión italiana de Francisco Messineo publicada bajo la dirección de Benedetto Croce y G. Gentile. Buenos Aires, Argentina: Editorial Claridad, 1955. Según Lowy, la misma frase de Marx se puede encontrar, en diversos contextos, en los escritos de Immanuel Kant, J. G. Herder, Ludwig Feuerbach, Bruno Bauer, Moses Hess y Heinrich Heine. Por ejemplo, en su ensayo sobre Ludwig Börne (1840), Heine ya la empleaba -en una manera positiva (aunque irónica)-: "Bienvenida sea una religión que derrama en el amaro cáliz de la sufriente especie humana algunas dulces, soporíferas gotas de opio espiritual, algunas gotas de amor, esperanza y creencia”. Moses Hess, en su ensayo publicado en Suiza en 1843, toma una postura más crítica (pero aún ambigua): "La religión puede hacer soportable [...] la infeliz conciencia de servidumbre [...] de igual forma el opio es de buena ayuda en angustiosas dolencias". La expresión apareció poco después en el artículo de Marx Acerca de la crítica de la filosofía del derecho de Hegel (1844)”, véase. Löwy, Michel. Marxismo y religión. ¿Opio del pueblo? <En línea>. [consulta: 20 febrero 2012]. Disponible en World Wide Web: <http://marxismocritico.files.wordpress.com/2011/10/marxismo-y-religic3b3n-opio-del-pueblo.pdf >

${ }_{61}$ Marx, Carlos. "Tesis sobre Feuerbach”, en: Marx, Carlos y Engels, Federico, op. cit. (n. 3), p. 11.
} 
Marcos López Oneto / Las metamorfosis del trabajo: del trabajo al empleo

\subsubsection{La preparación protestante para la centralidad del trabajo y el advenimiento del empleo}

Como se ha expuesto, la reforma protestante eleva el trabajo profesional a la categoría de actividad fundamental del hombre. El trabajo, ergo, ya no es una actividad degradante, como en la cultura greco-romana, o una actividad ambivalente, como en gran parte del Medioevo, sino todo lo contrario y más aún: un camino de redención espiritual cuyo desenvolvimiento estructurará completamente la sociedad, pues toda la actividad social girará en torno a él ${ }^{62}$.

Por cierto que no es objeto de esta investigación discutir la falsabilidad de la tesis de Weber sobre la relación entre la ascesis protestante y el espíritu del capitalismo. Sí, en cambio, resulta relevante destacar que la obra de Weber permite distinguir claramente la transformación que el trabajo, tanto conceptual como materialmente, experimentó durante la reforma; transformación que preparó el terreno para la creación del empleo asalariado, forma normativa típica del trabajo en la sociedad capitalista.

En efecto: el protestantismo y en particular el calvinismo, contribuyó a la expansión de la cultura del trabajo, entendido éste como actividad racional y metódica, base fundamental del capitalismo que, por cierto, y como estimamos justificado por Weber, no se inspira en el auri sacra fames

Menguando con el paso del tiempo el fundamento religioso de la idea de trabajo como fin en sí mismo, pero habiéndose irradiado en las sociedades europeas en todo caso una praxis que lo alza valóricamente, la posta ideológica sustentadora de la cultura del trabajo, que ve en este una actividad central de la sociedad, será tomada por la ilustración, en reemplazo de la ideología religiosa protestante.

Al final de la "Ética protestante y el espíritu de capitalismo", Weber reflexiona:

"El ascetismo se propuso transformar el mundo y quiso realizarse en el mundo; no es extraño, pues, que las riquezas de este mudo alcanzasen un poder creciente y, en último término, irresistible sobre los hombres como nunca se había conocido en la historia. La jaula ha quedado vacía, el capitalismo victorioso no necesita ya de este apoyo religioso, puesto que descansa en fundamentos mecánicos. También parece haber muerto definitivamente la rosada mentalidad de la riente sucesora del puritanismo, la "ilustración", y la idea del "deber profesional" ronda por nuestra vida como un fantasma de ideas religiosas ya pasada. El individuo renuncia a interpretar el cumplimiento del deber profesional cuando no puede ponerlo en relación directa con ciertos valores espirituales supremos o cuando, a la inversa, lo siente subjetivamente como simple coacción económica. En el país donde tuvo mayor arraigo, los Estados Unidos de América, el afán de lucro, ya hoy exento de su sentido

\footnotetext{
62 Según Charles Taylor, la veta puritana del protestantismo, en Inglaterra y en Norteamérica, desarrollaron una versión peculiarmente intensa y radical de lo que él denomina "afirmación de la vida corriente", que es una de las fuentes o ideas claves constituyentes de la cultura e identidad moderna. Véase. TAYLOR, Charles. Fuentes del yo. La construcción de la identidad moderna, $1^{\text {a }}$ edición, Barcelona, Espańa: Paidós, 2006, p. 310. Por "vida corriente" entiende aquellos "aspectos de la vida humana que conciernen a la producción y reproducción, es decir, el trabajo y la manufactura de las cosas necesarias para la vida, y nuestra vida como seres sexuales, incluyendo el matrimonio y la familia” (Ibid., p. 289). Coincidiendo con Michael Walzer, Taylor sostiene que uno de los motivos impulsores de la reforma calvinista fue el horror al desorden social por el cual "la pequeńa nobleza indisciplinada y los pobres sin oficio y sin hogar, la plebe de granujas, mendigos y vagabundos, planteaba una constante amenaza a la paz social” (Ibid., p. 312). Y también por el horror al desorden personal, a la vida licenciosa. Ambas clases de desorden se retroalimentan y generan caos, división. Una muy elemental reconstrucción semántica del término "diabólico", nos conduce a entender que dicho término significa división; y que, por cierto, se opone a lo "simbólico", que significa unidad.
} 
ético-religioso, propende a asociarse con pasiones puramente agonales, que muy a menudo le dan carácter en todo semejante al de un deporte. Nadie sabe quién ocupará en el futuro la jaula de hierro, y si al término de este monstruoso desarrollo surgirán nuevos profetas y se asistirá a un pujante renacimiento de antiguas ideas o ideales, o si, por el contrario, lo envolverá todo una ola de petrificación mecanizada y una convulsa lucha de todos contra todos"63.

\subsection{LA CONCEPCIÓN ILUSTRADA DEL TRABAJO}

Lo expuesto hasta ahora sugiere que es razonable pensar que el calvinismo preparó ideológicamente el advenimiento de la concepción ilustrada del trabajo, por cuanto consolidó una visión utilitaria, abstracta y racional de aquél, presupuesto ideológico y cultural del capitalismo ${ }^{64}$. Dicho proceso puede ser comprendido de la siguiente forma: en efecto, si estar entre los elegidos por Dios se manifiesta en el éxito en la vida terrenal, la vida es una actividad que debe estar orientada a la obtención de resultados en dicho plano, pues los resultados económicos inmediatos (la riqueza) prueba la predestinación. Se advierte así una relación utilitaria e individualista, puesto que se trabaja bajo la motivación precisa y determinada de obtener un resultado especial, la salvación.

El Calvinismo propone que la relación del hombre con Dios es personal, individual e intransferible. Los logros en el plano del trabajo tienen carácter individual. Cada hombre se encuentra puesto en el intríngulis de obtener plena prueba, independientemente de los demás, de su predestinación. La competencia económica enmascarará la competencia por conseguir la entrada en el reino de Dios. Lentamente comienza a prevalecer en las culturas de raigambre calvinista una espiritualidad utilitarista, ya que se trabaja con un fin muy preciso y de manera metódica, esperando un retorno a lo invertido: la salvación individual.

Pero en algún momento del decurso de este desarrollo histórico, y como resultado de complejos procesos sociológicos cuyo análisis trasciende los límites de esta investigación, la competencia económica se desespiritualizará y devendrá en pura competencia económica. Así fue como la identificación de la ascesis espiritual con el éxito material sirvió de base a la ética del capitalismo, porque se fue consolidando una cultura que valora positivamente todo aquello que se acerque a maximizar los rendimientos de la inversión (espiritual o económica).

Estaba entonces preparado el terreno para que la Ilustración retomara el concepto utilitario del trabajo, pero despojándolo de contenido religioso. Por consiguiente, "cuando John Locke (1632-1704) declaró el trabajo como fuente de la propiedad, el trabajo había superado otro escalón hacia la actividad más honrada del ser humano"65. Con el pensamiento ilustrado, el trabajo pasa convertirse definitivamente en la única fuente legítima de riqueza ${ }^{66}$.

Esta nueva transformación del trabajo, habiendo acontecido en el contexto de la ilustración, reconoce por cierto su matriz ideológica en el racionalismo y sus postulados de igualdad y libertad, en donde el hombre -libre e igual en dignidad y derechos- ocupa el centro del discurso

\footnotetext{
Weber, Max, op. cit. (n. 47), pp. 286-87.

Ibid., p. 127.

KöHler, Holm-Detlev; Martín, Antonio, op. cit. (n. 31), p. 14.

Ibid., p. 14.
} 
Marcos López Oneto / Las metamorfosis del trabajo: del trabajo al empleo

de construcción de la nueva sociedad sustentada en el reconocimiento de los derechos individuales fundamentales ${ }^{67}$.

El giro antropocéntrico que significó la ilustración y la modernidad, quizás pueda resumirse en la célebre definición de Kant:

"Ilustración es la salida del hombre de su autoculpable minoría de edad. Esta minoría de edad significa la incapacidad de servirse de su propio entendimiento sin la guía de otro. Uno mismo es culpable de esa minoría de edad cuando la causa de ella no reside en la carencia de entendimiento, sino en la falta de decisión y valor para servirse de sí mismo sin la guía de otro. Sapere aude! ¡Ten valor para servirte de tu propio entendimiento! He aquí el lema de la ilustración" 68 .

La venta de la fuerza de trabajo, por tanto, puede ser distinguida teóricamente en este orden ideológico, como un supremo acto que emana de la autonomía del hombre (un sujeto racional).

Así, están dispuestas las bases ideológicas jurídicas que la revolución industrial necesita para desencadenar toda su potencialidad. Por cierto, sin proletarios, esto es, sin hombres jurídica y formalmente libres "que, privados de medios de producción propios, se ven obligados a vender su fuerza de trabajo" ${ }^{69}$; no puede llegar a constituirse el modo de producción capitalista.

\subsection{LA CONCEPCIÓN DEL TRABAJO EN LA REVOLUCIÓN INDUSTRIAL ${ }^{70}$.}

Desde una perspectiva más bien externa, la revolución industrial podría ser descrita como el cambio que se produce en la Historia Moderna de Europa por el cual se genera el paso desde una economía agraria y artesana, cuya fuentes de energía son la muscular humana, animal, eólica e hidráulica, sin una estructura global de trabajo dependiente libre; a otra dominada por la industria, la aparición del fenómeno de las máquinas, la mecanización y la utilización del vapor como fuente de energía ${ }^{71}$, con una completa estructura normativa de trabajo dependiente libre, y funcional a

67 Para una revisión en profundidad de los aspectos ideológicos de este proceso: Alonso Olea, Manuel. op. cit. (n. 6), pp. 229291. Para una visión histórica y política: НовSBAwn, Eric. Las revoluciones Burguesas. Europa 1789-1848. Madrid, España: Ediciones Guadarrama, 1964. Para revisión y análisis de los aspectos jurídicos del proceso: Ruiz Mateos, Alfonso. Una filosofía del derecho en modelos históricos. De la antigüedad a los inicios del constitucionalismo. Madrid, Espańa: Editorial Trotta, 2002; Peces BARra, Gregorio. Curso de Derechos Fundamentales. Teoría general. Madrid, Espańa: Universidad Carlos III de Madrid/Boletín Oficial del Estado, 1999, pp. 154-204.

68 Kant, Immanuel. "Respuesta a la pregunta: ¿Qué es la ilustración?”, en: Maestre A., J. Romagosa (estudio preliminar y traducción). Qué es la ilustración. -5ª reimpresión-. Madrid, España: Tecnos, 2009, p. 17.

69 Nota de Federico Engels a la edición inglesa de 1888 del "Manifiesto del Partido Comunista". V. Marx, Carlos y Engels, Federico. op. cit. (n. 3), p. 111.

70 El término revolución industrial fue introducido por el historiador Arnold Toynbee (1851-1882) en sus "Lectures on the Industrial Revolution", Rivington, 1884; para referirse al desarrollo económico británico entre 1760 y 1840, aunque luego se le ha dado un significado más amplio. La historia de la revolución industrial cuenta con una formidable bibliografía según documenta Alonso Olea, Manuel. op. cit. (n. 6), p.361. También existen antecedentes del uso de la categoría revolución industrial en: Paul Mantoux (1857-1956), "La Révolution industrielle au XVIII siécle”, 1906; Karl Marx, en el Tomo I del "Capital”, 1867; John Stuart Mill, en los "Principles of political economy", 1848, y también en Federico Engels, en "La situación de la clase obrera en Inglaterra", 1845. Véase PARIAs, Louis-Henri (dirigida). Historia General del Trabajo. Tomo III. México: Ediciones Grijalbo, 1965, p. 9.

71 Recordemos que John Watt, en 1769, reparando en la Universidad de Glasgow, el pequeño modelo de la bomba de fuego de Newcomen, inventó el mecanismo de la bomba de vapor, máquina fundacional de la revolución industrial. La primera patente es de 1769. Y la primera máquina de vapor salida de las fábricas de Soho se libró en 1775 destinada a una mina de carbón de los Midlands, para la elevación del agua Parias, Louis-Henri (dirigida), op. cit., pp. 14-15. Para una visión a cerca de la transformación del mundo 
esas nuevas formas de producción. La revolución industrial, en importancia y por cierto haciendo las reservas y prevenciones del caso, para el desarrollo de la humanidad, sólo podría ser comparable con la revolución neolítica ${ }^{72}$.

El elemento aislado más típico de la Revolución Industrial fue, sin duda, la irrupción de la tecnología en la economía. Es la época de las invenciones y de los inventores; del incremento cuantitativo y cualitativo de la productividad de los factores; de la consolidación y concentración del capital financiero y de la sociedad mercantil anónima; del nacimiento de la clase proletaria y la reorientación de la división u organización del trabajo en función de las máquinas; de la migración del campo hacia la ciudad; del aumento demográfico; del cambio en las costumbres y preferencias de consumo de la gente; de la simbiosis entre ciencia y tecnología, y del cambio en la percepción del tiempo y del espacio, por obra de la rapidez en el transporte y las (tele) comunicaciones ${ }^{73}$.

El aumento de la producción y de la productividad que conlleva la Revolución Industrial, se traducirá en una poderosa oferta de los más variados bienes de consumo, sin precedentes de la historia de humanidad. Testimonio teórico de este fenómeno, es la frase con la cual Marx inicia El Capital: "La riqueza de las sociedades en que impera el régimen capitalista de producción se nos aparece como un inmenso arsenal de mercancías y la mercancía como su forma elemental"74.

Comienza, pues, a configurarse una nueva estructura social, una nueva cultura, una nueva sociedad; primero en Europa y Estados Unidos de Norteamérica y, a destiempo y asimétricamente, en el resto del mundo occidental. Se trata de la sociedad capitalista.

Existe bastante coincidencia entre los estudiosos del tema, respecto a que con la revolución industrial "el trabajo adquiere una nueva dimensión abstracta como tiempo, como actividad unitaria divisible en unidades mensurables en intervalos y dinero. Es un factor de producción y, al mismo tiempo, una relación contributiva en virtud de la cual quedan vinculados el individuo y la sociedad"75.

Puesto que el trabajo adquiere el status de un factor abstracto de producción, es decir, de una X cantidad de actividad humana para producir X cantidad de bienes, en los inicios de la revolución industrial, el trabajo fue tratado como una mercancía más, generándose las bases para la existencia de un mercado de trabajo y/o fuerza de trabajo en donde el factor dignidad humana es soslayado valóricamente. No es el hombre el que trabaja; el que lo hace es el proletario o asalariado, es decir, de aquél que vive apenas de la venta de su fuerza trabajo.

Pero convengamos en que ideológicamente la revolución industrial y la revolución francesa -motores de la modernidad-, y como ha propuesto Castel, siguiendo en esto a Pierre Rosan-

entre 1789 y 1848, debido a lo que se denomina la "doble revolución", esto es, la Revolución francesa de 1789 y la revolución industrial británica. Véase Новsвawn, Eric, op. cit. (n. 67).

72 Datando sus comienzos hace más 9.000 años atrás, es considerada la primera transformación radical de la forma de vida de la humanidad que pasa de ser nómada a sedentaria y de economía depredadora (caza, pesca y recolección) a productora (agricultura y ganadería). El término se debe a Vere Gordon Childe y se considera el cambio socio-cultural más profundo y radical que haya experimentado la humanidad. Vere Gordon Childe acuñó el término revolución neolítica, en su obra (Man Makes Himself, 1936). Existe versión en español: Gordon Childe, Vere. Los orígenes de la civilización. -21a reimpresión- México: Fondo de Cultura Económica, Eli de Gortari, 1996.

73 Para una completa descripción: Alonso Olea, Manuel, op. cit. (n. 6), pp. 229-270; Santos Ortega, Antonio y POVEDA ROSA, María. Trabajo, empleo y cambio social. Valencia, España: Tirant Lo Blanch, 2001, pp.70-138.

74 Marx, Carlos. El Capital. Crítica de la economía politica. Tomo I, traducción Wenceslao Roces. México: Fondo de Cultura Económica, 2009, p. 3.

75 KöHler, Holm-Detlev y Martín, Antonio, op. cit. (n. 31), p.16. 
Marcos López Oneto / Las metamorfosis del trabajo: del trabajo al empleo

vallon $^{76}$, tenía por proyecto un capitalismo utópico ${ }^{77}$. Firmes creyentes en la mano invisible y la libertad individual, por oposición al autoritarismo oscurantista y al corporativismo medieval, los revolucionarios no estaban en condiciones de anticipar históricamente la estructura desigual y contraria a la justicia social del tipo sociedad que comenzaba a configurarse. Así fue como a poco andar, Marat, uno de los pocos que se opuso a la ley Le Chapelier ${ }^{78}$ (que, entre otras materias, suprimió los gremios), se preguntaba: "Que habremos ganado destruyendo la aristocracia de los nobles si es reemplazada por la aristocracia de los ricos"79.

No se pasará revista aquí a las deplorables consecuencias sociales que dicha concepción del trabajo ocasionó a la humanidad ${ }^{80}$; indignidades reparadas en el siglo XX con el Derecho del Trabajo. Valga solo asentar que en los comienzos ilustrados individualistas, y como ha sido expuesto en innumerables oportunidades y por los más insignes autores, la revolución industrial racionalizará el empleo como una construcción jurídica mediante contratos civiles en donde el proletario, trabajador y/o empleado, será considerado en igualdad de condiciones fácticas y jurídicas en relación al empresario y/o empleador, asimilándose a una simple relación jurídica civil (contrato de arrendamiento de servicios). Dicha concepción, y a pesar de las nefastas consecuencias sociales que originó en sus inicios, sin embargo, representó un progreso respecto del sistema laboral del antiguo régimen, caracterizado por el vasallaje y el trabajo corporativo bloqueador de la libertad de trabajo.

Con la revolución francesa y la famosa Ley Le Chapellier, que suprime los gremios y el conjunto de bloqueos y trabas al ejercicio de las profesiones u oficios, comienza la historia moderna del trabajo entendido como empleo; como venta libre de fuerza trabajo en un mercado gobernado por la oferta y la demanda.

Pero rápidamente, por las lacerantes injusticias que tal concepción entrañaba que, por cierto, dieron origen la denominada cuestión social ${ }^{81}$; al socialismo; al movimiento sindical y las

\footnotetext{
76 Rosanvallon, Pierre. La nueva cuestión social. Buenos Aires, Argentina: Ediciones Manantial, 1995.

77 Castells, Robert, op. cit. (n. 43), p. 201.
}

78 Dicen los considerandos de Ley Le Chapelier: "Ya no hay corporaciones en el Estado; sólo existe el interés particular de cada individuo y en el interés general. A nadie le está permitido inspirar a los ciudadanos un interés intermedio, separarlos de la cosa pública con un espíritu de corporación (...) hay que volver al principio de que fijar la jornada para cada obrero es algo que corresponde a las convenciones libres de individuo a individuo; a continuación, al obrero le corresponde mantener la convención a la que ha llegado con quien lo ocupa", vid. Castells, Robert, op. cit. (n. 43), p. 189.

79 Citado por Castells, Robert, op. cit. (n. 43), p. 201.

${ }^{80}$ Surge una nueva forma de pobreza que se aglutinó en torno a la palabra "pauperismo"; imagénes que Víctor Hugo, en "Los Miserables”, inmortalizara. Dícese que es posible arruinar a un pobre, dejándolo caer en el "pauperismo”. Al respecto, Castel escribe: "El pauperismo era una categoría históricamente inédita de la desdicha del pueblo, constituida no sólo por la miseria material sino también por una degradación moral profunda. La industrialización había creado una suerte de condición antropológica nueva: una especie de nueva barbarie, que no era tanto un retorno al salvajismo anterior a la civilización como la invención de un estado de desocialización propio de la vida moderna, especialmente urbana”, vid. CaStells, Robert, (n. 43), op. cit., p. 221.

81 Fue el concepto con el que explicaba a fines del siglo XIX y hasta buena parte del siglo XX, el conjunto problemas y conflictos derivados del antagonismo entre capital y trabajo o bien, la objetivación social de la lucha de clases, como podría ser expresado en términos marxistas. Tradicionalmente se ha explicado el nacimiento del Derecho del Trabajo como una estrategia del sistema capitalista para modular la cuestión social, vid. Escribar Mandiola, Héctor. Tratado de derecho del Trabajo. Santiago, Chile: ZigZag S.A., 1944, pp. 31-51; Palomeque López, Manuel; Alvarez de la Rosa, Manuel. Derecho del Trabajo, 16a edición, Madrid, España: Editorial Universitaria Ramón Areces, 2008, pp. 44-47; Martín Valverde, Antonio; Rodriguez-Sañudo Gutierrez, Fermín; Joaquín García Murcia. Derecho del Trabajo - 18a edición-. Madrid, Espańa: Tecnos, 2009, p. 72. Por otra parte, en "La metamorfosis de la cuestión social", Robert Castells postula que la cuestión social "puede caracterizarse por la inquietud acerca de la capacidad para mantener la cohesión de una sociedad" (CASTELls, Robert. op. cit. (n. 43), p. 29). En nuestro país la "cuestión social” puede ser remontada al surgimiento de los primeros asentamientos urbanos en la ciudad de Santiago que se generan con la migración 
huelgas; la sociedad capitalista, para asegurar su reproducción material e ideológica, y estabilizar su desarrollo, generará las primeras normas jurídicas laborales, reconfigurando una concepción del empleo ya no liberal-individualista, sino progresivamente en perspectiva social-participativa, con énfasis en la regulación jurídica laboral del mercado de trabajo por la vía de asegurar a los trabajadores derechos mínimos irrenunciables, para así mejorar su posición negocial y diferenciar valóricamente el trabajo de otros factores productivos: toda vez que "el trabajo no es una mercancía”, dirá la OIT ${ }^{82}$.

Lo expuesto anteriormente sugiere que, con matices y desarrollos temporales y geográficos asimétricos, es posible distinguir en gran parte de los Estados del mundo occidental, incluido por cierto el chileno, dos etapas jurídicas institucionales claramente diferenciadas en la historia del empleo.

Un primera etapa que, iniciándose en las primeras décadas de la revolución industrial y extendiendo su vigencia hasta fines del siglo XIX, se caracterizará por una concepción del trabajoempleo comprendido éste como una relación jurídica civil y mercantil, en cuya virtud un hombre formalmente libre, sin protección social alguna, vende su fuerza de trabajo (el proletario) a otro sujeto que es formal y materialmente libre, esto es, al capitalista o dueño de los medios de producción. Esta concepción del trabajo-empleo, es la propia del Estado Liberal de Derecho.

La segunda etapa será racionalizada por la doctrina como una superación del Estado Liberal de Derecho, porque el trabajo-empleo ya no será considerado una mercancía despojada de su dignidad humana intrínseca, sino todo lo contrario, será reconocido como un derecho humano fundamental, impregnado de contenido ético jurídico, razón por la cual pasará a convertirse en

campo-ciudad y coinciden, evidentemente, con el primer "proceso industrializador (1860-1880). Un hito importante en este proceso acontece en 1872, cuando el Intendente de Santiago, Benjamín Vicuña Mackenna, en su proyecto de renovación urbana, buscó segregar a la "ciudad bárbara" de la "ciudad decente", a través de un camino de Cintura. El proyecto consistió en expulsar a los vagos y prostitutas del centro de la ciudad. Vid. Yañez Andrade, Juan Carlos. La intervención social en Chile. 1907-1932. Santiago, Chile: RIL editores, 2008, p.74. A su vez, la primera voz que se refiere de manera explícita a la cuestión social, es la de Augusto Orrego Luco, en una serie de artículos publicados en La Patria de Valparaíso en 1884 y reimpresos en 1897. Ibid., p.76. Sin embargo, será Juan Enrique Concha Subercaseaux, futuro dirigente del Partido Conservador, quien primero aborde de un modo más político la "cuestión social" ,con una acerada crítica al liberalismo económico, en su memoria de prueba para optar al título de abogado, "La cuestión obrera”, publicada en 1899, Ibid., p. 78. Otro hito importante en la toma de conciencia de la sociedad chilena frente al tema de la cuestión social, fue la huelga portuaria en Valparaíso, 1903; hecho que ha sido denominado como el "bautismo de sangre de la cuestión social", donde ésta "que ha sido negada en diarios, ateneos y cámaras legislativas, proclama y afirma así su existencia, al resplandor de un incendio y en presencia de unos cuantos cadáveres que han quedado tendidos en las calles de Valparaíso", según testimonia Jorge Gustavo Silva en "Legislación social y educación cívica", 1928, Ibid p., 83. A partir de estos hechos, se instala definitivamente el entendimiento a cerca de que, si no se soluciona la cuestión social, la sociedad chilena difícilmente podrá mantener la paz social. Así es como en 1907 comienza la discusión de la creación de la Oficina del Trabajo que, junto con la Ley de Habitaciones Obreras de 1906, son los inicios más claros de la intervención social en Chile que, en materia laboral, alcanza un punto decisivo con el primer Código del Trabajo, en 1931. Para recopilación de los principales antecedentes bibliográficos precursores ideológicos de la cuestión social en Chile y también para su comprensión crítica: Grez Toso, Sergio. La cuestión social en Chile: ideas $y$ debates precursores (1804-1902). Santiago, Chile: DIBAM, 1997. Otras perspectivas, síntesis y enfoques de la cuestión social en Chile: Cruzat, Ximena; Tironi, Ana. "El pensamiento frente a la cuestión social en Chile en: Berrios Caro, Mario, et al. El Pensamiento en Chile: 1830-1910. Santiago, Chile: Nuestra América Ediciones, 1987; Morris, James Oliver. Las elites, los intelectuales y el consenso: estudio de la cuestión social y del sistema de relaciones industriales de Chile. Santiago, Chile: Ediciones del Pacífico, 1967; Ortiz Letelier, Fernando. El movimiento Obrero en Chile (1891-1919). Santiago, Chile: LOM, 2005. Y para una revision del marco histórico general en el cual se distingue la cuestión social en Chile, Vid. SALAZAR, Gabriel; Pinto, Julio. Historia contemporánea de Chile, 10a reimpresión, 5 tomos. Santiago, Chile: LOM editores, 2010.

82 OIT. Declaración de Filadelfia, 10 de mayo de 1944. <En línea>. [consulta: 20 febrero 2011]. Disponible en World Wide Web: $<$ http://www.ilo.org/ilolex/spanish/iloconst.htm\#annex>. 
Marcos López Oneto / Las metamorfosis del trabajo: del trabajo al empleo

una institución configuradora o fundante del estado en perspectiva social de derecho, producto de un proceso racionalizador garantístico ${ }^{83}$.

En efecto, la cuestión social producirá un estado de toma de conciencia respecto a que el caos que importa el desarrollo desbocado de la sociedad capitalista, puede llevar a la desintegración de ella. El mejoramiento de las condiciones mínimas de trabajo producirá un efecto de integración social de los trabajadores, recalibrando al sistema capitalista, el cual, mediante tal estrategia, obtendrá el equilibrio puesto en duda por la cuestión social. La mejora de las condiciones de trabajo también redundará en mejoras en los niveles de consumo de los proletarios, lo cual, a su vez, aumentará la producción de bienes y se entrará en un círculo virtuoso hasta cierto nivel de productividad e ingresos. Por otra parte, el reconocimiento de la dignidad intrínseca que importa el trabajo, conducirá a la sociedad capitalista, vista como sistema social, a la autocomprensión de la viabilidad y sustentabilidad de ella sólo en función del reconocimiento de los derechos fundamentales sociales, cuya inobservancia genera condiciones de profunda inestabilidad social. El paradigma de este modelo, por cierto, fue el Estado de Bienestar de la Europa de fines de la segunda guerra mundial y mediados de los años setenta. Se trata de "Los treinta años gloriosos" de que hablará alguna vez Jean Fourastie ${ }^{84}$

\subsection{LA CONCEPCIÓN DEL TRABAJO DE LA ÉPOCA FORDISTA: EL EMPLEO ASALARIADO DIGNO}

El fordismo podría ser definido como el sistema predominante de organización social de la producción del capitalismo del siglo XX (sobre todo el desarrollado en U.S.A. y Europa Central y, por cierto, con experiencias o desarrollos asimétricos en el resto del mundo). Se posiciona históricamente entre 1930-1975, y se lo caracteriza por la irrupción de la producción en masa estandarizando productos y servicios; por la complementariedad entre la producción masiva y el consumo masivo; la intensificación y racionalización de la producción y el aumento constante de la productividad, todo esto, por cierto, sustentado en un contexto institucional democrático garante de la estabilidad económica social ${ }^{85}$.

En sus origenes, el paradigma fue teóricamente formulado por un grupo de ingenieros, gerentes y contadores que adquirieron el nombre de "movimiento de los sistematizadores", por el énfasis declarado en poner fin al caos e improvisación en la organización industrial. Frederick Wislow Taylor (1856-1915) se convirtió en el máximo representante de dicho movimiento. Su obra maestra se llamó "management científico" (1911). Las ideas de Taylor sobre gestión empresarial fueron aplicadas y desarrolladas por Henry Ford y Alfred Sloan, directores de Ford Motor Company y de General Motors, respectivamente. El ejemplo histórico de tal sistema de producción, fue el automóvil modelo T Ford. El tiempo necesario para la producción del coche se redujo de 12, 5 horas en 1908 a 93 minutos en 1914; mientras el precio pasó de 850 US\$, en 1908 a 290, en $1924^{86}$.

El modelo también importaba elevar el nivel adquisitivo de los obreros, para que así pudieran consumir los mismos productos que producían. Henry Ford populariza el salario "five dollar

\footnotetext{
83 Monereo Pérez, José Luis. "Evolución y futuro del derecho del trabajo: el proceso de racionalización jurídica de la cuestión social”, en: Derecho Laboral, XVIV, n² 203, julio-setiembre, España, Madrid, 2001, p. 430.

84 Fourastie, Jean. Les trentes glorieuses ou la revolution invisible de 1946 a 1975. París, Francia: Artheme Fayard, 1975. Cfr. Castells, Robert, op. cit. (n. 43), p. 393.

85 Köhler, Holm-Detlev y Martín, Antonio, op. cit. (n. 31), pp. 372-387; Ramos Zincke, Claudio. La transformación de la empresa chilena. Santiago, Chile: Universidad Alberto Hurtado, 2005, pp. 15-24.

86 Köhler, Holm-Detlev y Martín, Antonio, op. cit. (n. 31), pp.370-413)
} 
day" por 8 horas de trabajo al día, implementada en enero de 1914 que fue un salario muy superior al promedio de la época. Y puesto que los nombres de Ford, Taylor y Sloan están indisolublemente ligados a la génesis y posterior desarrollo de la forma de organización del trabajo del paradigma aludido, es que también se conoce como paradigma de la producción en masa Taylorista-FordistaSloanista. Habiendo comenzado en la industria automotriz y mecánica, este forma de organización del trabajo será el modelo racionalizador del capitalismo predominante del siglo XX, que se irradiará a todas las industrias de producción de bienes y servicios, con la prevención, ciertamente, de que se trata de modelos o tipos ideales cuyas concreciones y aproximaciones históricas varían cualitativa y cuantitativamente ${ }^{87}$.

El derecho del trabajo clásico puede ser comprendido como el ordenamiento jurídico laboral del sistema fordista de producción. Porque el derecho del trabajo no niega la sociedad capitalista, sino que, todo lo contrario, la legítima jurídicamente, pues:

"asume una función esencialmente política (de estricta y deliberada política del Derecho) de legalizar a la clase obrera integrándola jurídicamente en el orden de convivencia imperante en la comunidad política. Se trata, pues, de ajustar el ordenamiento jurídico individualista del capitalismo a las exigencias de integración de la clase obrera y de racionalización de las condiciones de existencia y uso de la fuerza de trabajo en el mundo de las relaciones de producción capitalista" ${ }^{88}$.

Tenemos así que, desde una perspectiva sociológica jurídica, el derecho del trabajo cumple la función de regular y organizar las relaciones de producción capitalista, facilitando la dinámica de la economía y mejorando las condiciones de existencia vital de los trabajadores. El Derecho del Trabajo descomplejiza el conflicto capital v/s trabajo, institucionalizándolo y, de esta forma, lo integra haciéndolo parte de la estructura normativa de la sociedad.

En palabras de Monereo:

"El Derecho del Trabajo ha asumido una tarea de gestión racionalizadora de la fuerza de trabajo en el mundo de las relaciones de tipo económico cuyo objeto es el trabajo. Desde este punto de vista, el ordenamiento laboral obedece a una doble exigencia de racionalización jurídica en la regulación de las relaciones sociales: facilitar el funcionamiento de la economía y asegurar la mejora de las condiciones de trabajo y de vida de los trabajadores" 89 .

\footnotetext{
87 Ramos Zincke, Claudio, op cit. (n. 85), p. 9.

88 Monereo Perez, José Luis. Introducción al nuevo derecho del trabajo. Valencia, España: Tirant Lo Blanch, 1996, p. 21. Prácticamente no existe desacuerdo en la doctrina científica sobre la función transaccional, de compromiso o integración social o bien, sobre el carácter capitalista de derecho del trabajo, para referir la idea de que se trata de un derecho que pretende orientar el conflicto entre capital y trabajo por cauces pacíficos para los efectos de reproducir material e ideológicamente a la misma sociedad capitalista. Aparte del citado, entre otros autores puede consultarse: Alonso Olea, Manuel; Casas BaAmonde, María Emilia. Derecho del Trabajo. Madrid, España: Universidad de Madrid/Facultad de Derecho, 1989, pp.60-65; Borrajo Dacruz, Efrén. op.cit. (n. 23), pp. 125-149; Irureta Uriarte, Pedro. "El impacto de los principios jurídicos en el Derecho del Trabajo", en: Carbonell, Flavia, et al (Coord.). Principios Jurídicos. Análisis y crítica. Santiago, Chile: Universidad Alberto Hurtado/AbeledoPerrot/Thomson Reuters, 2011, pp. 291-314; Montoya Melgar, Alfredo. Derecho del Trabajo - 29a edición -. Madrid, España: Tecnos, 2008, pp. 31-33; Palomenque López, Manuel Carlos; Alvarez de la Rosa, Manuel. Derecho del Trabajo - 16a edición -. Madrid, España: Editorial Universitaria Ramón Areces, 2008, pp. 39-94; Martín Valverde, Antonio; Rodriguez-Sañudo Gutierrez, Fermín; García Murcia, Joaquín. op. cit. (n. 81), pp. 60-65.

89 Monereo Perez, José Luis, "Evolución y futuro... (n. 83), pp. 430-431.
} 
La constitución óntica-jurídica que realiza el Derecho del Trabajo del trabajador y del empleador y, ciertamente, de la relación jurídica laboral, en perspectiva, puede ser vista como la culminación de un lento proceso de dignificación del trabajo por cuenta ajena prestado en condiciones de libertad, en donde la regulación jurídica del trabajo pasa a ser un pilar central de la estructura de la sociedad.

En la época fordista del capitalismo se consolida también la distinción entre trabajo y empleo. El trabajo es el género que engloba el conjunto de las actividades humanas manuales y/o intelectuales, que transforman utilitariamente el orden natural de la materia con el fin de producir satisfactores de necesidades, denominados genéricamente bienes y servicios. Y el empleo, una especie de trabajo, prestado por cuenta ajena, sujeto a regulaciones jurídicas de protección y dignificación que generan su paulatina desmercantilización.

La sociedad fordista se estructurará en función del empleo en términos tales que este pasará ser norma de vida. No requiere una fundamentación muy compleja la afirmación relativa a que la educación y el aprendizaje social están orientados hacia el cumplimiento de la normatividad psico-social-económica del empleo. No debería resultarnos dificultoso convenir, por tanto, en que la sociedad está organizada de forma tal, que, mayoritariamente, se participa de ella en la misma medida que se tiene un empleo y que, se es ciudadano y persona, o se "es alguien en la vida", en la medida en que se es empleado.

Los lazos de solidaridad y comunicación social, así como la estructuración de la sociedad en agrupamientos humanos, también vienen determinados por el empleo. La ubicación que la persona tiene en la escala de los empleos, determina su lugar en la estratificación de clases de la sociedad y, por tanto, en la cultura y sistema de creencias. Así, el empleo ha devenido en el principal medio de inclusión en las sociedades de mercado, pues la pérdida del empleo, en gran medida, se traduce en una especie de pérdida de la condición humana. No en vano, la sociedad capitalista de la época fordista o postfordista, ha sido definida como una sociedad salarial, para referir la idea de una sociedad estructurada sobre una relación social que considera principal, a saber: la relación salarial, de empleo y/o jurídica laboral.

Pero la sociedad salarial está en crisis ${ }^{90}$. La situación actual, escribe Castel,

"Está marcada por una conmoción que recientemente ha afectado a la condición salarial: el desempleo masivo y la precarización de las situaciones de trabajo, la inadecuación de los sistemas clásicos de protección para cubrir estos estados, la multiplicación de los individuos que ocupan en la sociedad una posición de supernumerarios, "inempleables", desempleados o empleados de manera precaria, intermitente. Para muchos, el futuro tiene el sello de lo aleatorio" ${ }^{\prime 1}$.

O, como ha dicho Hannah Arendt "nos enfrentamos con la perspectiva de una sociedad de trabajadores sin trabajo, es decir, sin la única actividad que les queda. Está claro que nada podría ser peor"92.

Volveremos sobre ese tema en el capítulo IV.

Castells, Robert, op. cit. (n. 43), p.13.

Arendt, Hannah, op. cit. (n. 4), p.17. 
El desempleo, es uno de los principales problemas del mundo actual. Porque el empleo es un bien escaso e inestable ${ }^{93}$. Cuando las tasas de desempleo suben, resulta muy difícil recuperar sus niveles óptimos. Por otra parte, el desempleo es un factor de injusticia social y de inestabilidad social y amenaza de la paz, porque en el trabajo no sólo están en juego elementos objetivos (sobrevivencia, reproducción), sino que también factores subjetivos: el trabajo es factor de constitución de identidad de las personas. Así, quien no trabaja pierde en cierta forma su condición de persona: de sujeto ligado y vinculado al mundo. Desligados del trabajo asalariado, las personas y sus familias pierden capacidad sicológica y material de desarrollar una vida social digna. Los estudios de campo de Paul Lazarsfeld, Marie Jahoda y Hans Zeisel, sobre los desempleados y/o parados de Marienthal ${ }^{94}$, muestran que la tesis de la centralidad del trabajo no ha perdido fuerza, y que hay buenas razones para seguir manteniéndola, a pesar de las tesis del fin del trabajo ${ }^{95}$.

La complejidad del problema descrito ha movido a las sociedades a generar reorientaciones de sus sistemas jurídicos laborales en términos que éstos manifiesten de una forma más clara y categórica, a nivel del derecho positivo, objetivos de eficiencia económica en armonía con las clásicos de justicia social y protección al trabajador. Porque lo que está juego con la crisis de la sociedad salarial, es la estabilidad y equilibrio global de la sociedad capitalista. No realizar las reformas regulatorias europeas en las últimas décadas del siglo XX, habría significado el colapso del sistema y el ingreso a una etapa de incertidumbre y caos social. El paso de un Derecho del Trabajo unidireccional, que sólo tiene por fin la protección al trabajador, a uno bidireccional, que concilia protección al trabajador o justicia social, con eficiencia económica o protección a la fuente del empleo, es la etapa evolutiva actual de nuestra disciplina que ha permitido mantener vigente, con cambios y reformas, la sociedad salarial ${ }^{96}$.

93 Alonso Olea, Manuel. El trabajo como bien escaso. < En línea>. Revista del Ministerio del Trabajo y Asuntos Sociales de España, No 33. [consulta: 20 febrero 2012]. Disponible en World Wide Web: <http://www.meyss.es/es/publica/pub_electronicas/destacadas/ revista/numeros/33/estudio1.pdf>

94 Köhler, Holm-Detlev y Martín, Antonio, op. cit. (n. 31), pp. 19-22. El "Estudio de los parados de Marienthal" es una investigación clásica de la sociología del trabajo. Data de 1931, y se realizó en la localidad de Marienthal, Austria. La narrativa es la siguiente: cuando tenían trabajo, a los habitantes Marienthal les faltaba el tiempo para otras actividades. Si lograban participar de ellas, cobraban un sentido existencial enriquecedor. Después de un tiempo, ahora desempleados y aún cuando gozan de subsidios, se modifica el ritmo de sus vidas: los domingos y días de fiesta han perdido toda significación, lo mismo que las actividades que, cuando tenían empleo, deseaban realizar. "La nueva situación ya no se integra en el esquema temporal preexistente: a un mundo más pobre en acontecimientos y en estímulos corresponde una percepción más empobrecida del tiempo”, Ibid., p. 22. Existe una edición en español del estudio: Lazarsfeld, Paul; Jahoda, Marie; Zeissel, Hans. Los parados de Marienthal: sociografia de una comunidad golpeada por el desempleo. Madrid, España: Las Ediciones de la Piqueta, 1996.

95 El inicio sistemático del debate sobre el fenómeno de denominado fin del trabajo o fin de la sociedad del trabajo, puede ser situado en el XXI Congreso Alemán de Sociología en 1982. En aquél evento, Claus Offe describió la crisis de la sociedad del trabajo como un proceso signado (a) por la creciente diversificación y pluralidad de las formas del trabajo eliminando su carácter unitario y descomponiendo las categorías trabajador o empleado; (b) la disminución del peso de la jornada laboral en el tiempo vital, y (c) la consecuente pérdida de centralidad del trabajo en la vida de la gente. Vid. KöHLER, Holm-Detlev y Martín, Antonio, op. cit. (n. 31), p.24. Pero también existen otros autores que aportan una perspectiva apocalíptica o radical, como André Gorz: "Crítica de la división del trabajo", 1977; "Metamorfosis del trabajo: búsqueda de sentido", 1995; "Miserias del presente, riqueza de lo posible, 1998); y, Jeremy Rifkin: "El fin del trabajo: nuevas tecnologías contra puestos de trabajo: el nacimiento de una nueva era”, 1997. Un resumen de las críticas a la tesis del fin del trabajo, en: De la Garza Toleda, Enrique. "Fin del trabajo o trabajo sin fin". En su: "Tratado latinoamericano de sociología del trabajo. - 1a edición -. México: FCE, 2003, pp. 755-733.

96 Para un completo análisis jurídico laboral de estos cambios, puede consultarse la reciente publicación escrita en español: López Oneto, Marcos. El principio de protección a la fuente del empleo en Chile. Pasos hacia un derecho del trabajo bidireccional. Santiago, Chile: LegalPublishing/Thomson Reuters, 2013; OJeda Avilés, Antonio. La deconstrucción del Derecho del Trabajo. Madrid, España: La Ley/Grupo Wolters Kluwer, 2010. Desde un punto de vista sociológico, hoy comienza a hablarse postfordismo. En la búsqueda de una nueva categoría que de cuenta de los cambios en las formas de organización productiva de la sociedad, se han propuesto términos tales como "Especialización Flexible" -Piore \& Sabel-, "Nuevos Conceptos de Producción" -Kern \& Schumann-, "Lean 


\section{BIBLIOGRAFÍA}

Abbagnano, Nicola. Diccionario de Filosofía. $4^{\text {a }}$ edición en español 1a reimp, traducción de José Estebán Calderón y Alfredo N. Galleti, actualizado por Giovanni Fornero. México: Fondo de Cultura Económica, 2007.

Alonso García, Manuel. Derecho del Trabajo. Barcelona, España: Bosh Editor, 1960.

Alonso Olea, Manuel; Casas Banmonde, María Emilia. Derecho del Trabajo. Madrid, España: Universidad de Madrid/Facultad de Derecho, 1989.

Alonso Olea, Manuel. Introducción al derecho del trabajo -4a edición-. Madrid, España: Editorial Revista de Derecho Privado/Editoriales de Derecho Reunidas, 1981.

Arendt, Hannah. La condición humana. Traducción Ramón Gil Novales. Buenos Aires, Argentina: Ediciones Paidós, 2009.

Aristóteles. Ética Nicomaquea. Politica. México: Harla, 1990.

Berdichevsky, Bernardo. Antropología Social: Introducción. Una visión global de la sociedad. Santiago, Chile: LOM, 2002.

Berman, Harold. La formación de la tradición jurídica de Occidente - $1^{\text {a }}$ edición-. Traducción Mónica Utrilla de Neira. México: Fondo de Cultura Económica, 2001.

Borrajo Dacruz, Efrén. Introducción al derecho del trabajo -19a edición-. Madrid, España: Tecnos, 2010.

Cabanellas de Torres, Guillermo. Compendio de Derecho Laboral - 3a edición-. Buenos Aires, Argentina: Editorial Heliastra, 2001.

Castells, Robert. Las metamorfosis de la cuestión social. Una crónica del salariado. Buenos Aires, Argentina: Paidós, traducción Jorge Piatigorsky, 2009.

Castells, Manuel. La era de la información. Economía Sociedad y Cultura. 3 tomos. Traducción del original en inglés por Carmen Martínez Gimeno. México: Siglo XXI Editores, 2008.

Cruzat, Ximena; Tironi, Ana. "El pensamiento frente a la cuestión social en Chile”, en: Berrios Caro, Mario, et al. El Pensamiento en Chile: 1830-1910. Santiago, Chile: Nuestra América Eds., 1987.

Dawson, Christopher. Historia de la cultura cristiana - 2a edición -. México: FCE, 2006.

De la Garza Toledo, Enrique. "Fin del trabajo o trabajo sin fin”, en su: Tratado latinoamericano de sociología del trabajo. México: FCE, 2003.

Escribar Mandiola, Héctor. Tratado de derecho del Trabajo. Santiago, Chile: Zig-Zag S.A., 1944.

Production" -Womack, Jones \& Roos-, "Toyotismo" -Dohse, Jurgens \& Malsch-, "Antropocentric Production Systems -Charles-, "After Fordism" -Boyer \& Durant-, "Producción Masiva Flexible" -Coriat-, "Diversified Quality Production" -Streeck-. Con todo, en esta tesis seguimos la propuesta conceptual de Ramos Zincke, en cuanto a utilizar el término "postfordismo" para referir el modelo de producción que estaría superando al fordismo y cuyas características principales serían: adaptabilidad estratégica, flexibilidad organizativa, calificación y pleno uso de las capacidades humanas, reflexibilidad organizacional, redes de empresas; uso intensivo de tecnologías de la información y comunicación; intensificación y extensión del trabajo; incertidumbre y reducción del empleo estable, y debilitamiento de la estructura sindical (Ramos Zincke, Claudio. op. cit. (n. 85), p.17. Para una visión panorámica de las discusiones teóricas sobre el postfordismo, puede consultarse los clásicos: HyMAN, Richard y streeck, Wolfgang (comps). Nuevas tecnologías y relaciones industriales. Traducción Elvira Cortés Pizano. Madrid, España: Ministerio de Trabajo y Seguridad Social, 1993; Sayer, Andrew y Walker, Richard. La nueva economía social. Reelaboración de la división del trabajo. Traducción Emilio Gimeno Reinoso Madrid, Espańa: Ministerio de Trabajo y Seguridad Social, 1994. Otras reconstrucciones más recientes que pueden ser consultadas: Santos Ortega, Antonio y Poveda Rosa, María. Trabajo, empleo y cambio social. Valencia, Espańa: Tirant Lo Blanch, 2001; Letamendia, Francisco. Estructura política del mundo del trabajo: fordismo y posfordismo. Madrid, Espańa: Tecnos, 2009. Para una perspectiva y proyección sociológica global de los cambios: Castells, Manuel. La era de la información. Economía Sociedad y Cultura. $7^{\text {a }}$ reimpresión, 3 tomos. Traducción del original en inglés por Carmen Martínez Gimeno. México: Siglo XXI Editores, 2008 . 
Fouraties, Jean. Les trentes glorieuses ou la revolution invisible de 1946 a 1975. París, Francia: Artheme Fayard, 1975.

Gayo. Institutas. Traducción Alfredo di Pietro. Buenos Aires, Argentina: Abeledo-Perrot, 1997.

Gordon Childe, Vere. Los orígenes de la civilización. México: Fondo de Cultura Económica, 1996.

HarRIs, Marvin. El desarrollo de la teoría antropológica. Una historia de las teorías de la cultura - $16^{a}$ edición Traducción Ramón Valdés del Toro Madrid, Espańa: Editorial Siglo XXI, 2008.

Hegel, Guillermo Federico. Filosofía del Derecho. Introducción de Carlos Marx -4a edición-. Traducción Angélica Mendoza de Montero, de la versión italiana de Francisco Messineo publicada bajo la dirección de Benedetto Croce y G. Gentile. Buenos Aires, Argentina: Editorial Claridad, 1955.

Hyman, Richard y StreecK, Wolfgang (comps). Nuevas tecnologias y relaciones industriales. Traducción Elvira Cortés Pizano. Madrid, España: Ministerio de Trabajo y Seguridad Social, 1993.

Hobsawn, Eric. Las revoluciones Burguesas. Europa 1789-1848. Madrid, España: Ediciones Guadarrama, 1964.

Kant, Immanuel. “Respuesta a la pregunta: ¿Qué es la ilustración?”, en: Maestre A.; J. Romagosa (estudio preliminar y traducción). Qué es la ilustración. Madrid, España: Tecnos, 5a reimp., 2009.

KöHler, Holm-Detlev; Martín, Antonio. Manual de la sociología del trabajo y de las relaciones laborales. Madrid, España: Delta Publicaciones, 2005.

LaZARsfeld, Paul et al. Los parados de Marienthal: sociografía de una comunidad golpeada por el desempleo. Madrid, España: Las Ediciones de la Piqueta, 1996.

Leroi-Gourhan, Andre. El gesto y la palabra. Traducción Felipe Carrera D. Caracas, Venezuela: Ediciones de la Universidad Central de Venezuela, 1971.

Letamendia, Francisco. Estructura politica del mundo del trabajo: fordismo y posfordismo. Madrid, España: Tecnos, 2009.

Lewin, Robert; A. Foley, Robert. Principles of human evolution. Oxford, Inglaterra: Blackwell Science Ltd, 2004.

López Oneto, Marcos Eduardo. El principio de la protección a la fuente a la fuente del empleo en Chile. Pasos hacia un Derecho del Trabajo bidireccional. Santiago, Chile: LegalPublishing Thomson Reuters, 2013.

Loyseau, Charles. A Treatise of Orders and Plain Dignities. New York, Estados Unidos: Cambridge University Press, 2007.

Martín Valverde, Antonio et al. Derecho del Trabajo -18 a edición-. Madrid, España: Tecnos, 2009.

Marx, Carlos. El Capital. Crítica de la economía política. México: Fondo de Cultura Económica, tomo I, traducción Wenceslao Roces, 2009.

Marx, Carlos; Engels, Federico. Obras Escogidas. Tomo I. Moscú, Rusia: Editorial Progreso, 1976.

Monereo Pérez, José Luis. "Evolución y futuro del derecho del trabajo: el proceso de racionalización jurídica de la cuestión social”, en: Revista Derecho Laboral, XVIV (203), pp. 429-499, julio-septiembre, España, Madrid, 2001.

Monereo Pérez, José Luis. Introducción al nuevo derecho del trabajo. Valencia, España: Tirant Lo Blanch, 1996.

Montoya Melgar, Alfredo. Derecho del Trabajo - 29a edición -. Madrid, España: Tecnos, 2008.

Morris, James Oliver. Las elites, los intelectuales y el consenso: estudio de la cuestión social y del sistema de relaciones industriales de Chile. Santiago, Chile: Ed. del Pacífico, 1967.

Nougrer, Louis-René. "La prehistoria”, en: Parias, Louis-Henri. Historia General del Trabajo. Tomo I, traducción Joaquín Romero Maura. México: Ediciones Grijalbo, 1965.

Ojeda Avilés, Antonio. La deconstrucción del Derecho del Trabajo. Madrid, España: La Ley/Grupo Wolters Kluwer, 2010.

Ortiz Letelier, Fernando. El movimiento Obrero en Chile (1891-1919). Santiago, Chile: LOM, 2005.

Palomenque López, Manuel Carlos; Álvarez de la Rosa, Manuel. Derecho del Trabajo -16a edición. Madrid, España: Editorial Universitaria Ramón Areces, 2008. 
Marcos López Oneto / Las metamorfosis del trabajo: del trabajo al empleo

Parias, Louis-Henri (dirigida). Historia General del Trabajo. México. Tomo III. Ediciones Grijalbo, 1965.

Platón. "Las leyes, o de la Legislación”, en: Él mismo. Obras completas. Madrid, España: Aguilar, 1966.

Peces Barba, Gregorio. Curso de Derechos Fundamentales. Teoría general. Madrid, España: Universidad Carlos III de Madrid/Boletín Oficial del Estado, 1999.

Ramos Zincke, Claudio. La transformación de la empresa chilena. Santiago, Chile: Universidad Alberto Hurtado, 2005.

Rosavallon, Pierre. La nueva cuestión social .Buenos Aires, Argentina: Ediciones Manantial, 1995.

Rosas González, Antonio. "Pautas y procesos de evolución en el linaje humano”, en: Soler, Manuel (coord.). Evolución: la base de la biología .Madrid, España: Proyecto Sur, 2002.

Ruiz Mateos, Alfonso. Una filosofía del derecho en modelos históricos. De la antigüedad a los inicios del constitucionalismo. Madrid, Espańa: Editorial Trotta, 2002.

Salazar, Gabriel; Pinto, Julio. Historia contemporánea de Chile. 10a reimpresión, 5 tomos. Santiago, Chile: LOM editores, 2010.

Santos Ortega, Antonio; Poveda Rosa, María. Trabajo, empleo y cambio social. Valencia, España: Tirant Lo Blanch, 2001 .

SAYer, Andrew; Walker, Richard. La nueva economía social. Reelaboración de la división del trabajo. Traducción Emilio Gimeno Reinoso. Madrid, Espańa: Ministerio de Trabajo y Seguridad Social, 1994.

Stefoff, Rebecca. Humans: an evolutionary history. Origins and first human. New York, Estados Unidos: Marshall Cavendish Corporation, 2010.

Supiot, Alain. Crítica del derecho del trabajo. Madrid, España: Ministerio del Trabajo y Asuntos Sociales.

The Cambridge Encyclopedia of Human Evolution, 1992.

Torres, Guillermo. Compendio de Derecho Laboral-3a edición -. Buenos Aires, Argentina: Editorial Heliastra, 2001.

Walker Linares, Francisco. Nociones elementales de derecho del trabajo. Santiago, Chile: Editorial Nascimiento, 1957.

Weber, Max. La ética protestante y el espiritu del capitalismo. 3a reimp. Traducción Luis Legas Lacambra. México: Fondo de Cultura Económica, 2008.

Yañez Andrade, Juan Carlos. La intervención social en Chile. 1907-1932. Santiago, Chile: RIL editores, 2008.

Textos Electrónicos:

Alonso Olea, Manuel. El trabajo como bien escaso <En línea>. Revista del Ministerio del Trabajo y Asuntos Sociales de España, No 33. [consulta: 20 febrero 2012]. Disponible en World Wide Web: <http://www.meyss.es/es/ publica/pub_electronicas/destacadas/revista/numeros/33/estudio1.pdf>.

Rojas Flores, Jorge. Los trabajadores desde la colonia hasta 1973. <En línea>. disponible [Consulta: 2 noviembre 2010]. Disponible en World Wide Web: <http://www.bibliotecaobrera.cl/wp-content/uploads/2008/10/lostrabajadores-chilenos-desde-la-colonia-hasta-1973-jorge-rojas-flores.pdf $>$.

Löwy, Michel. Marxismo y religión. ¿Opio del pueblo? <En línea>. [consulta: 20 febrero 2012]. Disponible en World Wide Web: <http://marxismocritico.files.wordpress.com/2011/10/marxismo-y-religic3b3n-opio-del-pueblo. pdf>.

OIT. Declaración de Filadelfia (10-05-1944). <En línea>. [consulta: 20 febrero 2011]. Disponible en World Wide Web: <http://www.ilo.org/ilolex/spanish/iloconst.htm\#annex>.

VAtin, Francois. Trabajo, ciencias y sociedad. Ensayos de sociología y epistemología del trabajo. <En línea>. Buenos Aires, Argentina: Trabajo y Sociedad, CEIL-PIETTE, Lumen-Humanitas, 2004. [Consulta: 20 febrero 2012] Disponible en World Wide Web: <http://www.ceil-piette.gov.ar/docpub/libros/trcs.html\#intr>.

Velasquez, Óscar. ¿Hay esclavos en la ciudad platónica? < En línea>. DIADOKHE, Universidad Diego Portales. [Consulta 14 enero 2011]. Disponible en World Wide Web: <http://www.diadokhe.cl/media/platonica/politeia_c.pdf>. 